
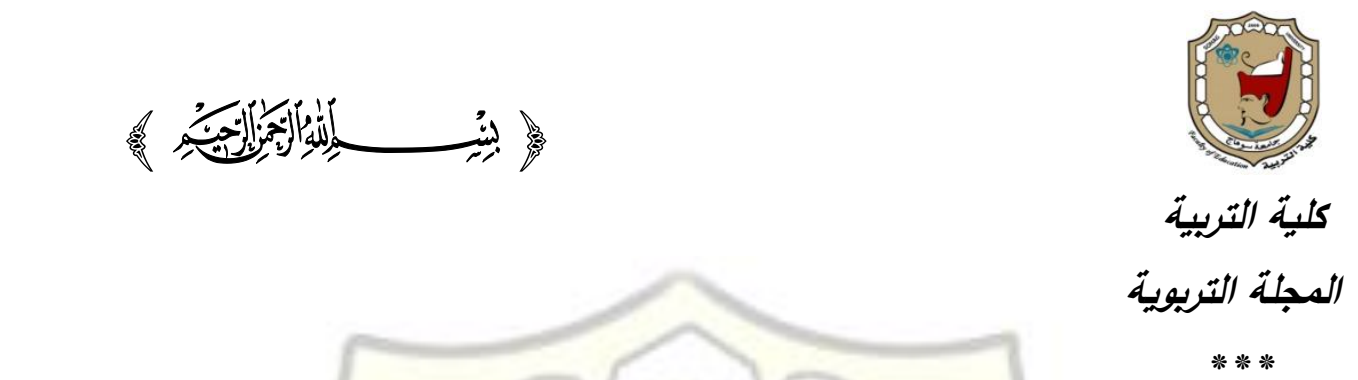

فاعلية استغدام استراتيجية (K.W.L) في ثدريس هقرر طرق التدريس علي تنـية التصصيل المعرفي لدي الطالبات المعامهات بجامعة القصيم، وتصسين اتجاهاتهن نموه

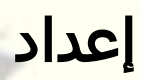

داء ليساء شعبـان أحمد أبوزيد

أستاذ مساعد مناهج وطرق تدريس الاقتصاد

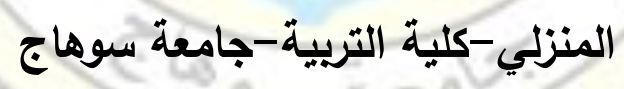

المجلة التربوية ـ العدد الحادي والستوز ـ مايو 19 19 م

Print:(ISSN 1687-2649) Online:(ISSN 2536-9091) 


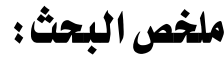

هلف البحث الحالي إلي استقصاء فاعلية استخدام استراتيجية(K.W.L) في تدريس مقرر طرق تدريس الاقتصاد المنزلي علي تنمية التحصيل المعرفي لاي الطالبات المعلمات بجامعة القصيم، وتحسين اتجاهاتهن نحو المقرر، ولتحقيق ذلك اختارت الباحثة عينة البحث اختيارًا قصدياً من طالبات قسم تصميم الأزياء بكلية التصاميم والاقتصاد المنزلي ببريده، كما استخدمت التصميم التجريبي للمجموعتين المستقلتين، إحداهما مجموعة تجريبية، وكان عددها (Yr) والأخرى مجموعة ضابطة، وعددها(Y Y)، وتم التأكد من تكافؤ المجموعتين، كما تم تصميم بعض موضوعات المقرروفقا لخطوات استراتيجية (K.W.L). وللإجابة عن أسئلة البحث قامت الباحثة بإعداد المواد التعليمية وأدوات القياس ، وتمثلت المواد التعليمية فيما يلي: ( دليل المعلمة - كتيب الطالبة)، أما أدوات القياس فكاتت (اختبار معرفي - مقياس الاتجاه نحو المقرر)، وتم التحقق من صدق وثبات المواد التعليمية وأدوات القياس، كما تم تدريس موضوعات مقرر طرق تدريس خاصة (1) للمجموعة التجريبية باستراتيجية (K.W.L)، في حين درست المجموعة الضابطة نفس الموضوعات بالطريقة التقليدية، وتم تطبيق أدوات القياس علي المجموعتين، وأشتارت النتائج إلي وجود فروق ذات دلالة إحصائية عند مستوي دلالة (ه.., •) بين المتوسطات الحسابية لارجات طالبات المجموعتين (التجريبية والضابطة) في الأختبار المعرفي، ومقياس الاتجاه نحو المقرر، وذلك لصالح المجموعة التجريبية ،كما وجلت علاقة ارتباطيه موجبة بلغت(9 ^, · ) بين متوسط درجات الطالبات في اختبار التحصيل المعرفي وبين متوسط إجاباتهن علي مقياس الاتجاه نحو المقرر، وفي ضوء النتائج قَُّّم البحث بعض المقترحات والتوصيات. 
" فاعلية استخدام استراتيجية (K.W.L) في تدريس مقرر طرق التدريس

Effectiveness of Using The (K.W.L) Strategy in theTeaching of

Teaching Methods Course on The Development of Cognitive

Achievement of Female Students in Qassim University, and

Improve Their Attitudes Towards It

\section{The summary:}

This current study is aimed to investigate the effectiveness of using the (K.W.L) strategy in teaching methods to develop the cognitive achievement of the female students in Qassim University and to improve their attitudes towards it. To achieve this study, the sample was selected randomly from the female students at the Department of Fashion Design, The Study was applied on two independent groups, one experimental group (32) and the other control group (32) and the equivalence of the two groups were determined. The contents of the textbooks were analyzed by the description of the course (K.W.L) strategy.

In order to answer the questions of the study, the researcher was prepared the materials and tools, which were as following : (teacher's manual - student's booklet). The tools were as following: (cognitive test measure of attitude towards the course), and the validity and stability of booth were checked، The experimental group was studied the subjects of special teaching methods (1) with the (K.W.L) strategy، The control group was studied the same subjects in the traditional way، The Study tools were applied to the two groups. The results indicated that there were statistically significant differences at the level of $(0,05)$ between the mean scores of the students of the two groups (experimental and control) in the cognitive test and the measure of the attitude towards the syllabus for the benefit of the experimental group. 
إيمانا بأهمية الدور الذي يؤديه المعلم المؤهل علي نوعية التعليم ومستواه؛ فقد اهتمت معظم الدول علي اختلاف فلسفاتها وأهدافها وسياساتها ونظمها التريوية والتعليمية بعملية إعداد المعلم وتأهيله أكاديميا ومهنيا، وأولتها جل إهتمامها؛ تسليما منها بأن المعلم هو محورالعملية التعليمية، وأساس نجاحها. فالمعلم من عوامل نجاح التعليم وتقدمه، فمهما توافرت الإمكانيات فلن تجدي شيئا دون معلم متمكن، ومؤمن بعمله وقيمته، ويمتلك الجوانب المهنية الحقيقية، وعلي رأسها معرفته الواسعة بطرق التدريس واستراتيجياته، وما يرتبط بهما من مهارات تدريسية

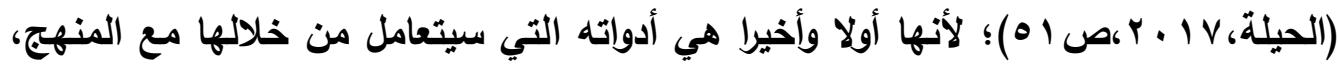
ولهذا اهتم عدد من التربويين العرب مع مطلع القرن الواحد والعشرون بقضية إعداد المعلم، وذلك لعدة أسباب، منها: استحداث طرق واستراتيجيات تلريس جديدة في كافة التخصصات،

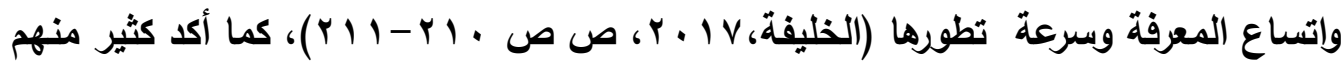
أن وراء كل طريقة تدريس ناجحة معلم ناجح، مرن، منفتح، ومطلع علي كل جديد في طرق التدريس واستراتيجياته؛ ولا يتحقق ذلك إلا من خلال دراسته لمقررات طرق التريس بكلية

يعد مقرر طرق التدريس من المقررات التريوية وطيدة الصلة بمهنة التعليم، ويهدف إلي إعداد الطالب/المعلم لحياته المهنية والأكاديمية، من خلال تزويده بالمعارف، وإكسابه

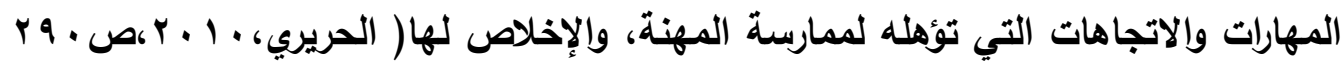

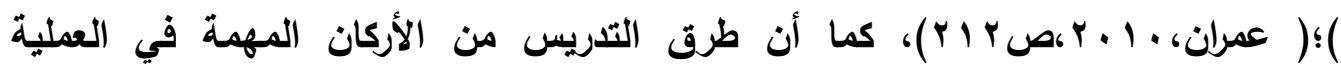

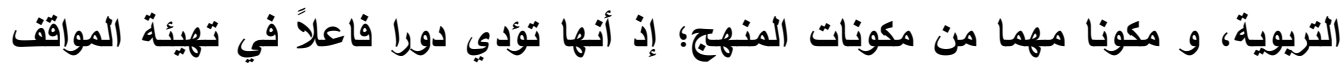
التعليمية، وتناول المادة العلمية، ولايستطيع المعلم الاستغناء عنها في تحقيق الأهداف

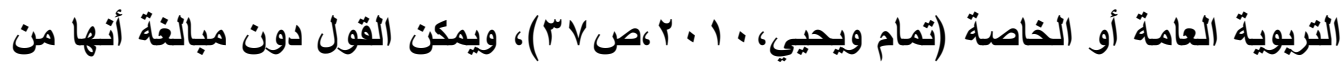
أكثر مكونات المنهج تحقيقا للأهداف؛ لأنها تحدد دور المعلم والمتعلم في العملية التعليمية، وتحدد الأساليب الواجب اتباعها والوسائل التعليمية التي يراعي استخدامها وأيضا الأنشطة التعليمية التي ينبغي القيام بها؛ لذلك فهي همزة الوصل بين الطالب والمعلم ومكونات المنهج

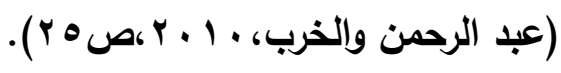


ونظراً للنهضة التعليمية والتطوير المستمر في مجال طرق التدريس ظهرت عدة طرق واستراتيجيات تدريسية تهدف إلي النهوض بالمستوي التعليمي للطلاب، وكان من بين هذه الطرق والاستراتيجيات، استراتيجيات التفكير فوق المعرفي و منها استراتيجية (K.W.L) (ماذا أعرف؟ - ماذا أريد أن أتعلم ؟- ماذا تعلمت؟) وتعد من أحدث استراتيجيات ما وراء المعرفة التي أثبتت بعض البحوث والدراسات فاعليتها في التدريس بمجالات وتخصصات

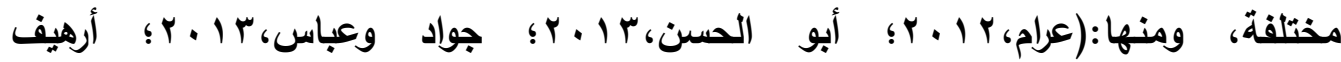

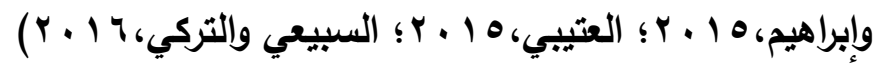

وتبني استراتيجية (K.W.L) علي مبدأ أساسي هو المعرفة السابقة للمتعلمين، حيث

تساعدهم في تحديد وتفعيل المعرفة السابقة مع المعلومات التي يتم تعلمها، مما يؤدي إلي هي توليد معرفة جديدة، وتتطلب إنشاء ثلاثة أعمدة، هي:(ماذا أعرف عن الموضوع؟ ، وما الذي أريد تعلمه من الموضوع؟، وما الذي تعلمته من الموضوع؟)، لذلك فهي من الاستراتيجيات التي تجعل المتعلم هو محور العملية التعليمية، وتركز علي زيادة ثقته بنفسه، وتجعل تعلمه ذا معني(Lauzon,2014)؛ (Adeel, 2015). و استراتيجية (K.W.L) من الاستراتيجيات التي تفعل التعليم الجمعي والتعليم الإستقلالي، فالمعلم يستخدمها مع جميع الطلاب، ثم ينقلهم بسهولة إلي الدراسة المستقلة؛

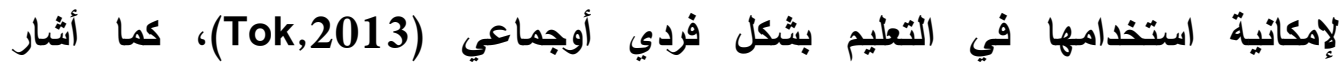
(2016, Zouhor,Jaskov and Bogdanovic) إلي مساعدة الطلاب علي تحسين الفهم العميق، وتثثكيل المفاهيم بالتحليل والدراسة، وأضاف

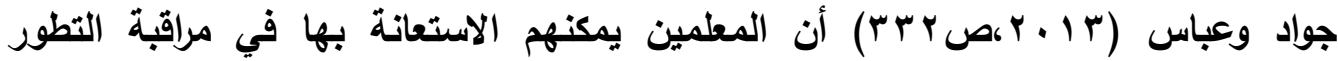
المعرفي للطلاب، واستيعابهم.

ويعد الاستيعاب والتحصيل هلفا مهما من أهداف العملية التعليمية لأي مقرر دراسي،

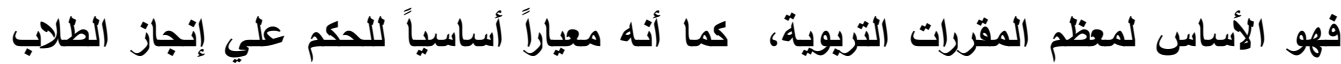
وتقدمهم دراسيا؛ ولكي يؤدي المعلم عمله علي أكمل وجه، ويطور نفسه؛ عليه أن يجداد معلوماته التريوية والثقافية ليؤدي دوره في خدمة طلابه، وخدمة مجتمعه ويحقى الآمال

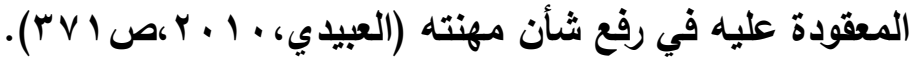


ولما كان رفع المستوي التعليمي للطلاب/ المعلمين هدفا مهما، فإن اتجاهاتهم نحوالمادة

لا تقل أهمية عن مستواهم التحصيلي؛ حتي يتمكنوا من ممارسة المهنة بنجاح. والاتجاهات الإيجابية نحو مقرر طرق التدريس مكونا رئيسا لبناء شخصية المعلم فاتجاه المعلم هو أهم عامل في عملية التعليم والتعلم، حيث يؤصل لحبه لمهنته وإخلاصه لها، كما

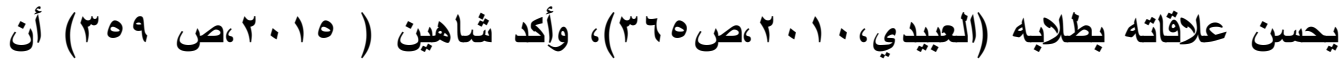
اتجاهات الطلاب نحو طرق التدريس تؤدي دورا أساسيا في العملية التعليمية، و تتيح لهم الفرصة لاكتساب معارف المقرر بسهولة ويسر، والإقبال علي دراسته، والإنتماء له والتتفق

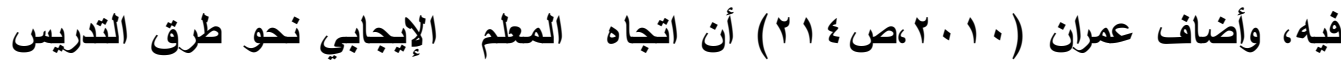
يحسن الاتجاه نحو التدريس بشكل عام؛ و يساعد علي إنجاز كثير من الأهداف التعليمية. ومن خلال طرق التدريس التي يتبعها المعلم في المواقف التعليمية تظهر انطباعات الطلاب واتجاهاتهم نحو الدراسة التي تساهم في دفع عملية تعلمهم، وتعديل استجاباتهم

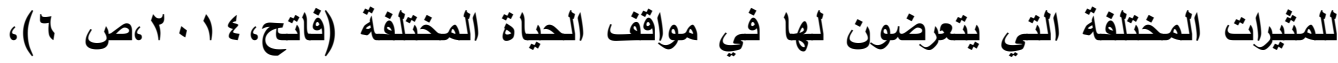
فكلما نجحت استراتيجية التدريس في تحقيق تفاعل أكثر مع الطلاب، كلما تحسنت اتجاهاتهم نحو المادة الدراسية، وازدادت دافعيتهم، وثقتهم بأنفسهم، ويالتالي تحسن تحصيلهم المعرفي؛ لأن تحسين الاتجاهات التعليمية يعد ثمرة تطبيق الاستراتيجيات التعليمية الناجحة (أبو حطب، بادئ

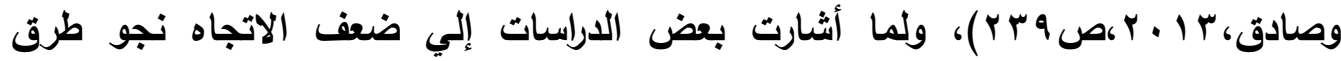
التدريس لدي المعلمين والمعلمات ببعض المجالات رغم أهميتها، ومن هذه الدراسات (Zaho\&Ting,2013)؛( الثويني، 0 (Y)؛ فقد أصبح من الضروري تنمية اتجاهات الطالبة/المعلمة نحو مقرر طرق تدريس الاقتصاد المنزبي، كما اتضح مدي الحاجة إلي تفعيل دورها في العملية التعليمية الذي أصبح ضروريا؛ فلم تعد الطالبة مجرد مستقبلة للمعلومات، بل عنصرا فاعلا إيجابيا نشطا، وهذا يتطلب استراتيجيات تدريس تساعد علي 


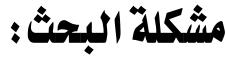

أصبحت الطرق التقليدية غير كافية لإحداث التغييرات المرجوة، ويناء شخصيات المعلمين والمتعلمين القادرة علي التعامل مع التطور ومتغيرات الحياة خاصة مع تراكم المعارف وتضخمها في شني المجالات ، كما أن واقع التدريس الجامعي اليوم قائم علي الطرق التقليدية التي تفتقر إلي تهيئة فرص تعليمية تتيح للطلاب القيام بأنثطة تعليمية مبنية علي التساؤلات و الفهم العميق للمعارف والمعلومات في كل التخصصات، وهذا ما

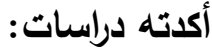

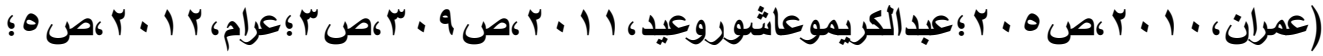

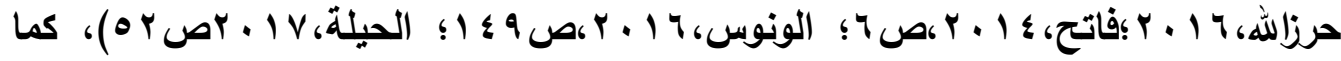
أوضحت أغلب الاراسات والبحوث أن مشكلات المدرسين المهنية تحددت فيما يلي:

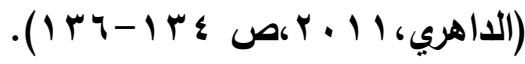

$$
\begin{aligned}
& \text { - ضعف إعدادهم علميا وتريويا. }
\end{aligned}
$$

- الاقتصار علي طريقة المحاضرة التقليدية دون الطرق الأخرى في التدريس. ومن خلال قيام الباحثة بالتدريس للطالبات/المعلمات بكلية التصاميم والاقتصاد المنزلي، وكذلك الإشراف عليهن في التدريب الميداني لاحظت ضعف أدائهن، وافتقارهن لتطبيق الجديد

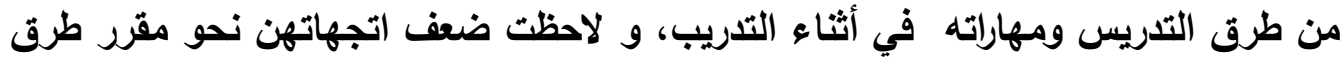
تدريس الاقتصاد المنزليكما لاحظت من خلال عملها بكنترول المواد التريوية لعدة سنوات

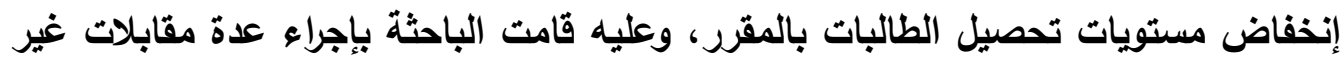
مقننة - كدراسة استطلاعية - مع أغلب الطالبات/المعلمات بالفرقة الثالثة اللاتي يدرسن باتهن المقرر، وقد أسفرت نتائج هذه المقابلات عن اتجاهاتهن السلبية نحو المقررات التريوية بشكل بالبه عام، ومقرر طرق تدريس الاقتصاد المنزلي بشكل خاص، وأرجعن هذه الاتجاهات السلبية إلي الي التهاتي صعوية استيعابهن للمعارف المتضمنة بهذا المقرر، وشعورهن بالملل خلال المحاضرات وإعراض بعضهن عن حضورها ، وإهتمام أغلب أعضاء هيئة التريس بالجانب المعرفي القائم علي الحفظ والاستظهار فقط، فضلا عن إهمال الجانب الوجداني الأي يهتم بمشاعرهن 
علي ضوء ذلك شعرت الباحثة بمشكلة البحث التي تمثلت في التدريس باستخدام طرق التدريس التقليدية التي تركز علي الحفظ والاستظهار، والمعرفة السطحية فقط ، مما ترتب عليه سلبية الطالبات، وصعوية استيعابهن للمعارف المتضمنة بالمادة، و ضعف اتجاهاتهن نحوها، فضلا عن شعور غالبيتهن بالملل في أثناء دراسة هذه المادة. ويالإطلاع علي توصيات الدراسات والبحوث السابقة وجلت الباحثة أن العديد منها يوصي باستخدام طرق تدريس فعالة في التدريس، ومن هذه الاراسات: دراسة فتح الله

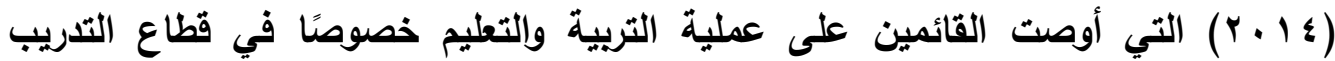
والتطوير بتظيم دورات تدريبية للمعلمين والمعلمات في جميع المراحل التعليمية عن استراتيجية (K.W.L) كاستراتيجية أثبتت فاعليتها، ويعتبر استخدامها في الدول العربية

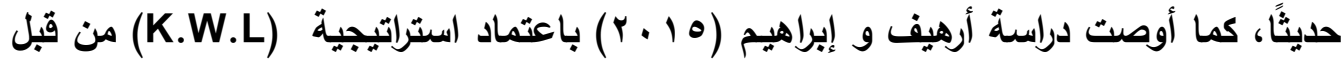
المعلمين وأساتذة الجامعة كاستراتيجية تدريسية حديثة تناسب طلاب الجامعة، في حين

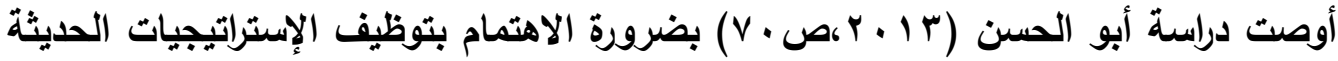
في التدريس والتواصل مع المعلمين في تنفيذها كاستراتيجية (K.W.L) ، كما أوصت بإعطاء دورات تدريبية للمعلمين قبل الخدمة وأثنائها حول هذه الاستراتيجية، وتوظيفها في عملية التدريس، بينما أوصت دراسة (2016) بouhor, et al., بضرورة توفير الموارد الكافية والتطوير المهني للمعلمين؛ لكي يستطيعون تنفيذ استراتيجية(K.W.L) بنجاح، كما أكد)(Wulandari,2017) أنه بدون استخدام استراتيجيات جيدة في التدريس مثل استراتيجية (K.W.L)؛ فسيؤدي ذلك إلي تأثير سيء في تعلم الطلاب للمادة الدراسية، لأنهم

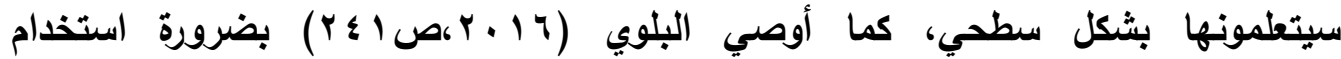
استراتيجية) (K.W.L) في معظم المواد الدراسية. وانطلاقاً من ندرة الدراسات التي تناولت استراتيجية(K.W.L) في مرحلة التعليم الجامعي، وكذلك ندرة الدراسات التي استهدفت تنمية اتجاهات الطالبات المعلمات نحو مقرر طرق تدريس الاقتصاد المنزلي-علي حد علم الباحثة- حيث لم تجد الباحثة دراسة تناولت استراتيجية (K.W.L) في مجال البحث الحالي؛ عكف البحث الحالي على الاستفادة من استراتيجياته التدريس الحديثة، من خلال استقصاء فاعلية استراتيجية(K.W.L) في تدريس التئية مقرر طرق تلريس الاقتصاد المنزلي. 
وتحددت مشكلة البحث في قصور طرق التدريس المتبعة في التدريس الجامعي في تحقيق أهداف المادة وتحسن مخرجات التعلم؛ الأمر الأي دفع الباحثة إلي استخدام استراتيجية)(K.W.L) في التدريس لتنمية التحصيل المعرفي والاتجاه نحو مقرر طرق تدريس(1) خاصة، ومن ثم حاول البحث الحالي الاجابة عن التساؤلات التالية:

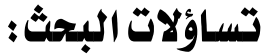

ويتطلب حل هذه المشكلة الإجابة عن الأسئلة التالية:

1 - ما التصور المقترح لتخطيط بعض موضوعات مقرر طرق تدريس خاصة(1) وفقا لخطوات استراتيجية (K.W.L)

ץ- ما فاعلية استراتيجية (K.W.L) في تحسين التحصيل المعرفي لاي الطالبات عينة

$$
\text { البحث؟ }
$$

ץ- ما فاعلية استراتيجية (K.W.L) في تكوين اتجاه إيجابي نحو مقرر طرق تدريس خاصة(1) لادي الطالبات عينة البحث؟

ع - ما العلاقة الارتباطية بين ارتفاع مستوي التحصيل - من خلال الاختبار المعرفي -

وتتمية الاتجاهات نحو مقرر طرق التدريس خاصة(1) - من خلال مقياس الاتجاه -

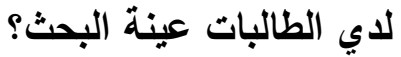

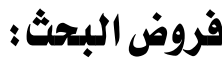

حاول البحث الحالي اختبار صحة الفروض التالية: 1 - يوجد فرق ذو دلالة إحصائية عند مستوي دلالة (ه ., •) بين متوسطي درجات تحصيل طالبات المجموعة التجريبية التلاتي درسن وفقا لاستراتيجية(K.W.L)، وطالبات المجموعة الضابطة اللاتي درسن بالطريقة التقليدية في التطبيق البعدي لاختبار التحصيل المعرفي لصالح طالبات المجموعة التجريبية. r - يوجد فرق ذو دلالة إحصائية عند مستوي دلالة (ه . , •) بين متوسطي درجات طالبات

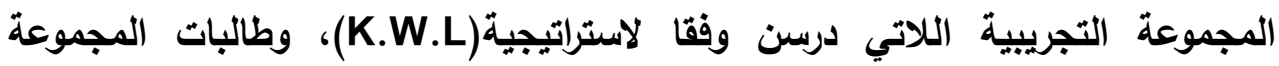
الضابطة اللاتي درسن بالطريقة التقليدية في التطبيق البعدي لمقياس الاتجاه نحو مقرر طرق تدريس خاصة( 1 ) لصالح طالبات المجموعة التجريبية. 
ץ- توجد علاقة ذات دلالة إحصائية عند مستوي دلالة (ه.,.) بين تحصيل طالبات

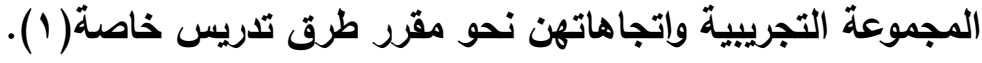

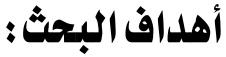

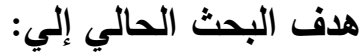
- تَعرُف فاعلية استراتيجية(K.W.L) في تحسين التحصيل المعرفي لاي الطالبات/ المعلمات في مقرر طرق تدريس خاصة( (1). - تَعرَف فاعلية استراتيجية(K.W.L) في تنمية اتجاهات الإيجابية نحو مقرر طرق تدريس خاصة(1) لاي الطالبات/ المطلمات.

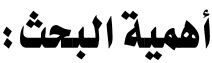
- يعد هذا البحث تلبية للاتجاهات الحايثة في التدريس التي تنادي باستخدام استراتيجيات تدريس جديدة في العملية التعليمية.

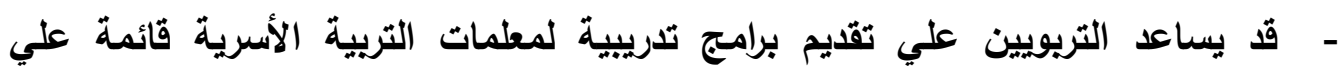

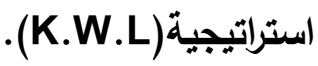
- قد يساعد في إرثاد أعضاء هيئة التدريس لاستخدام استراتيجية(K.W.L) في التدريس.

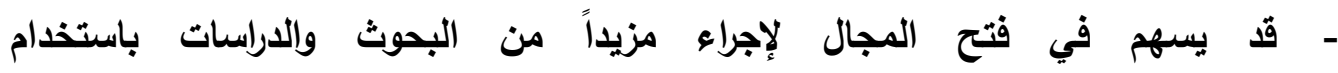
استراتيجية) (K.W.L) في مختلف المجالات. - يفيد طلاب العلم الباحثين عن استراتيجيات تدريس حيثة في مجال المناهج وطرق التدريس عامة وطرق تدريس الاقتصاد المنزلي خاصة. - قد يعمل علي لفت نظر معلمات التربية الأسرية علي رأس الخدمة إلي استخدام طرق واستراتيجيات تدريس جديدة في التطليم.

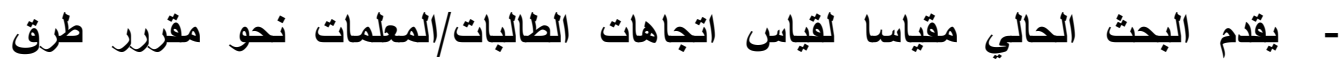
التدريس، وإختبارا معرفيا لبعض موضوعات مقرر طرق تدريس الاقتصاد المنزلي، يمكن الاستفادة منهما كأدوات قياس في دراسات أخري. 


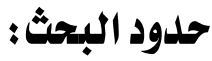

التزم البحث الحالي بالحدود التالية:

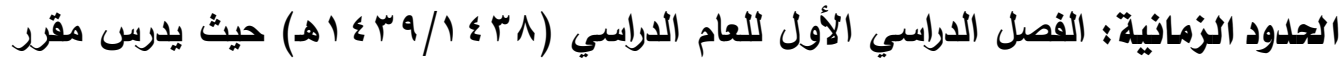
طرق تدريس خاصة(1) لطالبات الفرقة الثالثة بكلية التصاميم والاقتصاد المنزبي ببريده، وقد

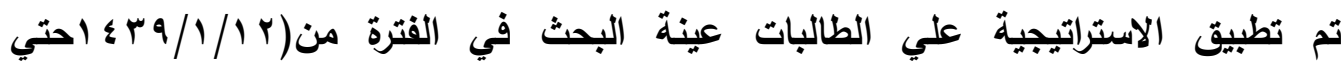
(ه) $\leqslant \mu q / r / r$

الحدود المكانية: كلية التصاميم والاقتصاد المنزلي بمدينة بريده، مقر عمل الباحثة حاليا. الحدود البشرية : تكونت عينة البحث من ( آ) من طالبات الفرقة الثالثة بكلية التصاميم

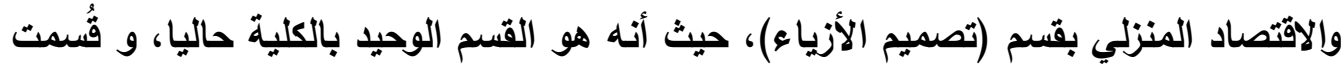

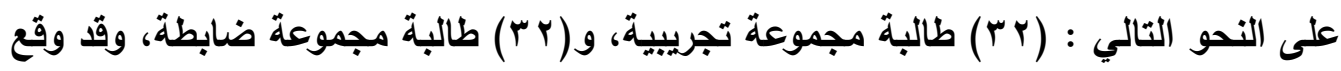
الاختيار علي طالبات الفرقة الثالثة بكلية التصاميم والاقتصاد المنزلي بشعبة(تصميم الأزياء)

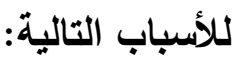
- الفرقة الثالثة هي البداية الحقيقية لاراسة أغلب المقررات التريوية لاسيما مقرر طرق تدريس خاصة(1)، وهذا وفقا للخطة الدراسية القائمة حاليا بالكلية (الرئاسة العامة لتعليم

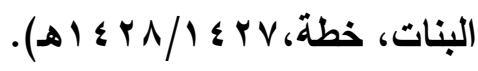
- طالبات الفرقة الثالثة درسن مقرر: مدخل إلي المناهج وطرق التدريس بالفرقة الثانية، ويعتبر متطلبا سابقا لاراسة مقرر طرق تلريس خاصة(1)، و يعتبرهذا شرطا من شروط (K.W.L) تطبيق استراتيجية - - طالبات الفرقة الثالثة بكلية التصاميم والاقتصاد المنزلي بثعبة (تصميم الأزياء) لم يخرجن بعد للتدريب الميداني- حيث يتدرين ميدانيا بالفرقة الرابعة- فتدريبهن علي بليه استراتيجية (K.W.L) قد يشجعهن علي استخدامها في التدريب الميداني. الحدود الموضوعية: بعض موضوعات مقرر طرق طرق تدريس الاقتصاد المنزلي المسمي

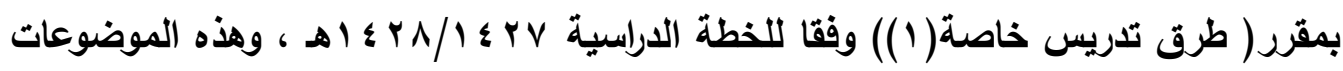
هي:(الأهداف التعليمة - مجالات الأهداف التدريسية - التخطيط لعملية التدريس - الأنشطة التعليمية - إدارة الصف وضبطه)، وقد تم اختيار تلك الموضوعات بترتيب ورودها بتوصيف الاهيف 
المقرر، كما أنها تدرس قبل موعد الاختبار الفصلي للمقرر؛ لأن موافقة إدارة الكلية علي تطبيق البحث مشروطة بانتهائه قبل موعد الاختبارات الفصلية.

\section{تحليلد مصطلحات البحث:}

تم تعريف مصطلحات البحث إجرائيًا كما يلي: استراتيجية (K.W.L):تعرفها الباحثة إجرائياً بأنها"الخطوات والاجراءات التدريسية المنظمة التي تعمل علي ريط المعرفة الجديدة بالمعرفية السابقة لدي الطالبات عينة البحث، وتساعد علي تكوين بني معرفية رصينة لايهن، وتتكون من الخطوات التالية:

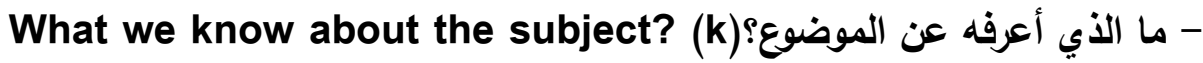
وهي خطوة تثخيصية لتعرف خبرة ومعرفة الطالبات السابقة عن الموضوع.

What we want to find out? (w) ما الأي أحتاج لتعلمه؟ وهي خطوة تحدد احتياجات ورغبات الطالبات ودافعيتهن للتعلم.

What we learned? (L) ما الأي تعلمتهـ وهي الخطوة التي يتم فيها تقويم وتحديد مدي استفادة الطالبات من التعلم. التحصيل المعرفي: " يعني مدي استيعاب الطلاب لخبرات دراسية معينة، من خلال المقرات الاراسية، ويقاس بالدرجة التي يحصل عليها الطلاب في الاختبارات التحصيلية المعدة لهذا

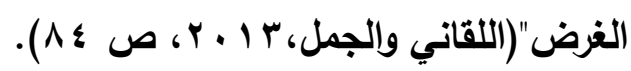

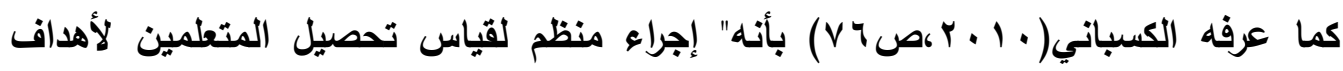
تعليمية محددة، أو هو إجراء منظم لقياس ما اكتسبه المتعلمون من حقائق ومفاهيم وتعميمات نتيجة لدراسة موضوع ما، أو وحدة تعليمية معينة". وستلتزم الباحثة بالتعريف السابق كتعريف اجرائي الاتجاه: هو"حالة من الاستعداد العقلي تولد تأثيراً دينامياً علي استجابة الفرد، تساعده علي اتخاذ القرارات المناسبة، سواء أكاتت بالرفض أم الايجاب فيما يتعرض له من مواقف له

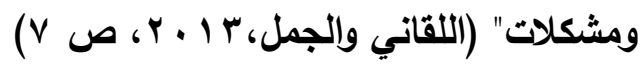

الاتجاه نحو مقررطرق التلدريس: هو" الاستعداد النفسي لاي الطالبات/معلمات التربية الأسرية

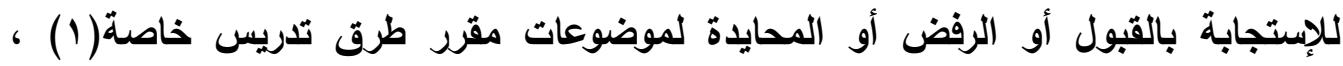


ويقاس بالدرجات التي حصلن عليها من خلال استجاباتهن علي مقياس الاتجاه المعد لهذا الغرض".

خطوات البحث: اتبع البحث الحالي الخطوات التالية: ا-الاطلاع على بعض الكتب والمراجع، ومسح الدراسات السابقة العربية والأجنبية في مجال البحث لتكوين خلفية نظرية والاستفادة منها في جميع مراحله. Y-إعداد المواد التعليمية، وتثمل ما يلي: أ- دليل المعلمة لتدريس بعض موضوعات مقرر طرق تريس خاصة(1) وفقا لاستراتيجية(K.W.L). (إعداد الباحثة) ب-كتيب الطالبة لاراسة بعض موضوعات مقرر طرق تريس خاصة(1) وفقا لاستراتيجية(K.W.L). ( إعداد الباحثة) r- إعداد أدوات قياس البحث، وتثثمل ما يلي: البي: أ- اختبار معرفي في مقرر طرق تدريس خاصة( ) إعل (إعداد الباحثة)

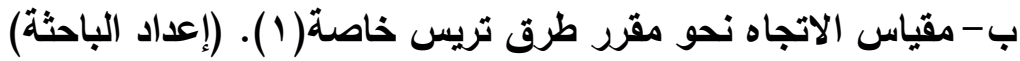
ع - اختيار عينة البحث من الطالبات معلمات الاقتصاد المنزلي بكلية التصاميم والاقتصاد المنزلي، وتم تقسيمهن إلي مجموعتين إحداهما تجريبية والأخرى ضابطة. ه- تطبيق أداتى البحث قبليًا علي المجموعتين (التجريبية والضابطة) لتحقيق التكافؤ بينهما. צ- تدريس بعض موضوعات مقرر طرق تريس خاصة(1) وفقا لاستراتيجية(K.W.L) للمجموعة التجريبية وتدريس تلك الموضوعات للمجموعة الضابطة بالطريقة التقليدية.

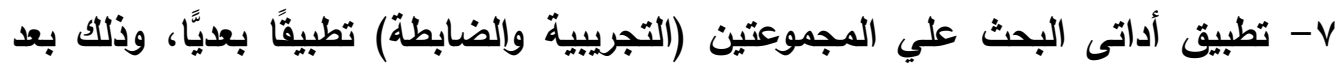
الانتهاء من التدريس. 1- المعالجات الإحصائية للتوصل إلي نتائج البحث. 9 - وناقشة النتائج وتفسيرها. • 1 - تقايم التوصيات والمقترحات. 
نشأة استزاتيجية)(K.W.L) )وتطورها :

تعد استراتيجية(K.W.L) إحدي استراتيجيات ما وراء المعرفة التي قدمتها "دونا أوجل"Dona Ogle ضمن برنامج فنون اللغة عام († (91) في الكلية الوطنية للتعليم

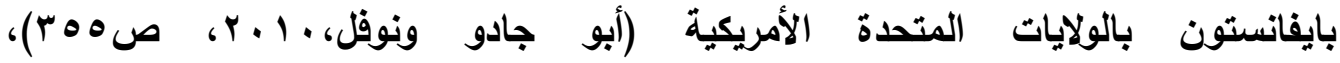
وضمنتها"أوجل" كل مراحل المعرفة الأساسية، وعليه تكونت هذه الاستراتيجية من ثلاث مراحل تمثلها الأحرف التالية: (L),(W),(L)(Lيشير كل حرف من هذه الأحرف إلي الحرف الأول من الكلمة الأجنبية الادالة علي مراحل المعرفة التي يقوم بها المتعلم وهي علي النحو التالي:

(Lauzon,2014; Wulandari,2017)

1 - المعرفة السابقة ويرمزلها بكلمة (Know) أي ماذا أعرف عن الموضوع؟ r - المعرفة المقصودة،ويرمز لها بكلمة (What) أي ماذا أريد أن أعرف؟

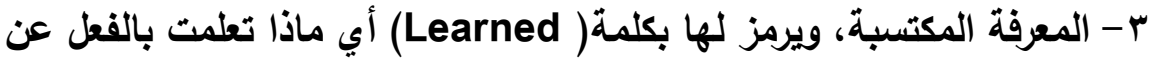
الموضوع؟، يمثلها المخطط التالي:

\begin{tabular}{|c|c|c|}
\hline $\bar{K}$ & $\mathbf{W}$ & $\mathbf{L}$ \\
\hline $\begin{array}{c}\text { What I know about } \\
\text { the subject? }\end{array}$ & $\begin{array}{c}\text { What I want to } \\
\text { know about the } \\
\text { subject? }\end{array}$ & $\begin{array}{c}\text { What I learned about the } \\
\text { subject ? }\end{array}$ \\
\hline ماذا أعرف عن الموضوع؟ & أعرف؟ أريدا $\quad$ أن & ماذا تعلمت بالفعل عن الموضوع؟ \\
\hline --------------- & ---------------- & ------------------ \\
\hline
\end{tabular}

تعريف استراتيجية)(K.W.L):

تعددت تسميات استراتيجية (K.W.L) فقد سميت بما يلي: جدول المعرفة، واستراتيجية تنشيط المعرفة السابقة، والتنظيمات المعرفية، والمنظور المفاهيمي، أو المُخطط المفاهيمي (جواد وعباس، Y • Y)، كما أطلق عليها أيضا المخطط العقلي، خرائط المعرفة، والجدول

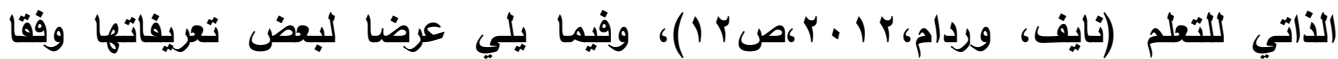




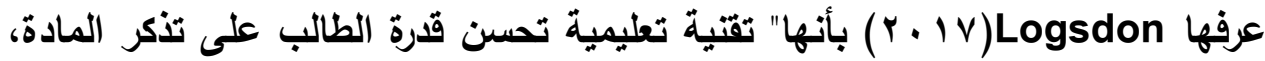
وتستخدم غالبا مع مواد القراءة الفوقية مثل: الكتب الدراسية ، والمقالات البحثية.

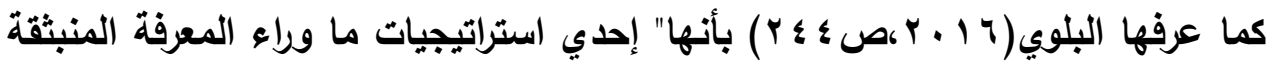
عن النظرية البنائية، وهي استراتيجية منظمة تتكون من ثثلاثة أعمدة، العمود الأول(المعرفة السابقة)، والعمود الثاني(المعرفة المقصودة)، والعمود الثالث(المعرفة المكتسبة)، وتعتمد إعتمادا كبيراً علي المعرفة السابقة للمتعلم". بينما عرف فتح الله (ع ا ب r) هذه الاستراتيجية " بالجدول الذاتي للتعلم الذي يتضمن مجموعة من الإجراءات التدريسية التي تقوم على مجموعة من التساؤلات التي توجه للطلاب

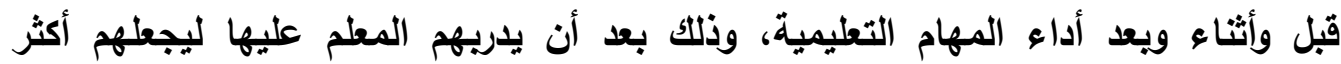
اندماجًا وفهمًا للمفاهيم وأكثر وعيًا بعمليات التفكير من خلال هذا الجدول".

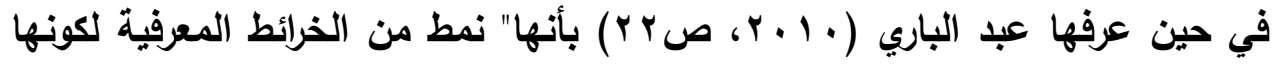

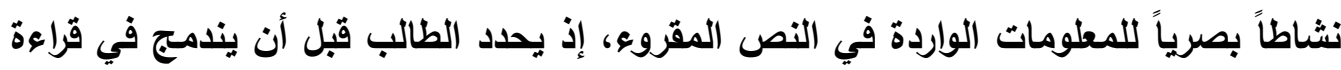
النص ما يعتقده عن الموضوع، وماذا يريد أن يعرف عن الموضوع ؟، وأخيرا يحدد ما الذي تعلمه ؟ ". وعرفها Kopp (2010,p10) بأنها"استراتيجية جيدة يستخدمها المعلمون لتشيط تفكير الطلاب في موضوع الدرس قبل حدوث التعلم الجديد". باسقراء التعريفات السابقة خلص البحث الحالي لتسميتها استراتيجية لكونها تتضمن عدة طرق، منها: المناقشة والعصف الذهني، والتعلم التعاوني، والأسئلة، والخرائط الذهنية، والقراعة الناقدة المتعمقة، مما يفعل العملية التعليمية ويجعلها ممتعة لدي الطالبات.

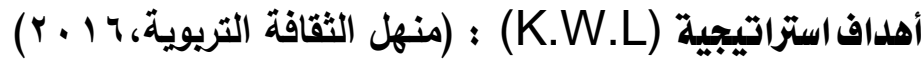
حددت "أوجل" (Ogle) أهداف استراتيجية (K.W.L) بهدفين رئيسين هما: ا - إدخال الطلاب في عملية القراعة النشطة لمادة الدراسة، التي تعنى بطرح الأسئلة التفكير في المفاهيم والتساؤلات الواردة في أثناء القراءة، r - تعزيز كفاية الطلاب في البحث عن المعلومات، وكتابة ملخصات ترتكز علي أهم مفاهيم وعناصر الموضوع محل الدراسة. 
أهمية استراتيجية(K.W.L ) لمعلمة التربية الأسرية( الاقتصاد المنزلي )؛ تساعد استراتيجية(K.W.L) ) (المعلمة أن تكون أكثر فاعلية في التدريس، وفي

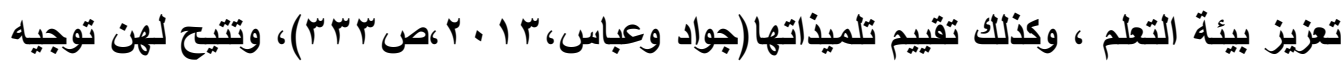

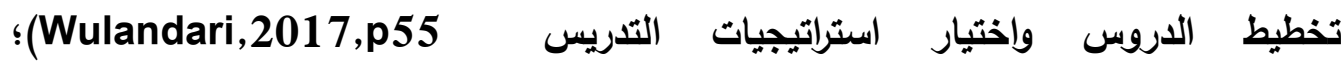

(Lauzon, 2014) أهمية استراتيجية (K.W.L ) للطالبة المعلمة: إن استراتيجية (K.W.L) من الاستراتيجيات التي تساعد الطالبة في تفعيل معرفتها

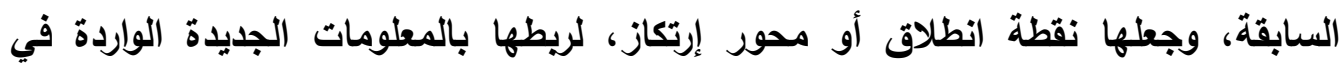
الموضوع المراد دراسته، ومراجعة ما تم تعلمه،لإستيعاب الموضوع، وتوظيفه بشكل ينسجم مع لع إن

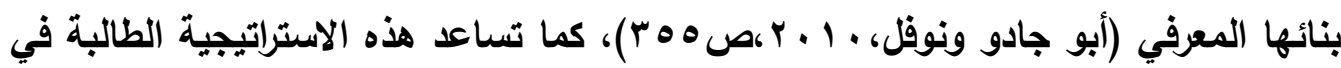

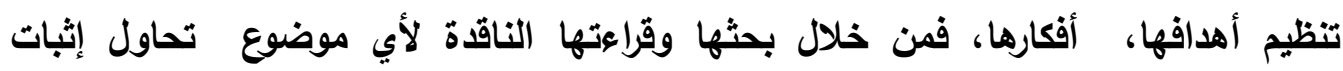
معلوماتها السابقة أو عدم إثباتها، كما تكسبها القدرة علي وضع الأسئلة الضرورية والمتنوعة ولها التي تعد ركيزة أساسية لتحديد أهدافها من التعلم، فضلا عن تنشيط الذهن، وزيادة انتباهها، ومثابرتها، وأخيرا فهي تقودها إلي مواصلة عملياتها المعرفية الجديدة، وتنمية تفكيرها (الوقفي، 11

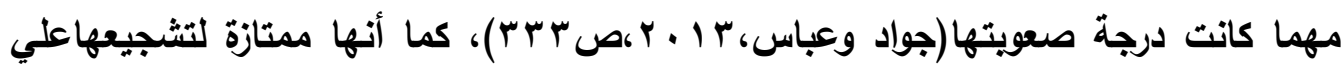

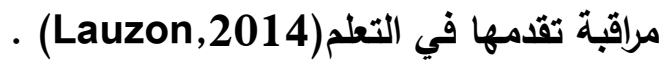
بإستقراء ما سبق يستخلص أن استراتيجية)(K.W.L) تساعد علي تحفيز المعرفة السابقة للطالبات، وتعمل علي تنظيم بنيتهن المعرفية عن طريق تنشيط المعرفة السابقة وربطها بالمعرفة الجديدة . ميزات استراتيجية) (K.W.L):

استراتيجية(K.W.L) هي إحدي الاستراتيجيات التي يمكن أن تبني المعرفة السابقة، وتطور مهارات التببؤ، ومهارات الكتابة ، كما تطور مهارات الاتصال في المجموعات التعاونية

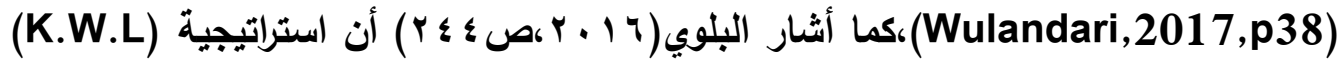
تثتمتع بعدة مزايا، منها: - تعزز فكرة التعليم الأي يجعل الطالب هو محور عملية التعلم. 
- تمكن المطلم من تعزيز بيئة التعلم الصفي.

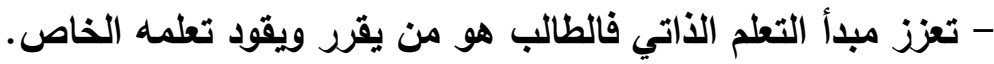
- تعمل علي جذب انتباه واهتمام الطلاب وتحفيز فضولهم العلمي. - تثجع الطلاب علي البحث عن معلومات جديدة باستمرار.

وأضاف) (Lauzon,2014) أنه يمكن استخدامها في أي مستوي تعليمي؛ لأنها تنمي مهارات الاتصال و تتيح للطلاب تقويم أنفسهم ذاتيا، وتنظم المعرفة التقريرية بما تتيحه من التهائ بناء المغنى لادهم، وتنمي تفكيرهم الناقد، و تزيد من دافعيتهم نحو التعلم. و أكل أديل (Adeel,2015) أن استخدام استراتيجية (K.W.L) تحسن التعليم من خلال: - جعل المحتوى ملائمًا ومفيدًا بناءً على المعرفة العابقة للطلاب. - الاحتفاظ بالمعلومات الجديدة لفترة أطول.

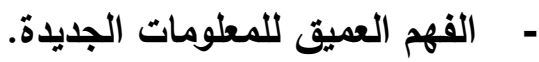
- ما تساعد في التفكير بوعي في الخطط والعمليات والتغيرات التي تحدث خلال التعلم

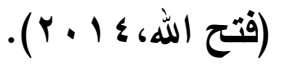
وياستقراء المميزات السابقة لاستراتيجية (K.W.L) يتضح أنها تتوافق بثدة مع أغلب

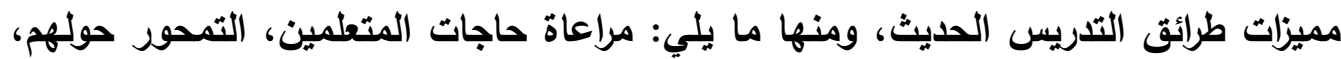
والعمل علي حفز دافعيتهم، وتثجعهم علي البحث والإبتكار، وتثجع التعلم الأتي، ويناء معرفتهم، وتنمية مهارات تحمل المسؤولية لايهم. عيوب استراتيجية)(K.W.L):

رغم المزايا المتعددة لاستراتيجية K.W.L) إلا أنه يعاب عليها أنها: (Wulandari, 2017,p39) - - يصعب تطبيقها على الطلاب دون معرفة مسبقة. - - ليست مناسبة للطلاب ذوي مستوى التفكير المنففض. - - ل - ليست فعالة لتطلم مواد الخيال. - - تستغرق وقتًا طويلا في عملية التعلم. 
خطوات تنفيذ استراتيجية(K.W.L):

تتدرج خطوات استراتيجية (K.W.L) )من المعرفة البسيطة، والخبرة السابقة الى مستويات متقدمة في التفكير والمعرفة، وفيما يلي عرضا لذلك:

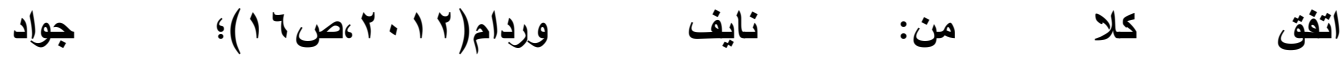

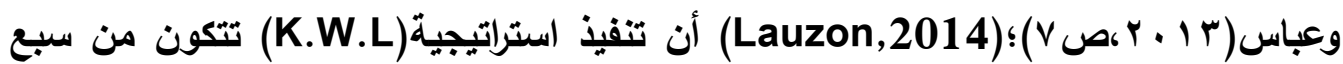

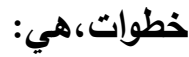

1 - الاعلان عن الموضوع: وفي هذه المرطلة يقوم المعلم بالإعلان عن الموضوع، وكتابته في

أعلى السبورة بخطٍ واضح.

r - الخطوة الأولي من مرحلة ما قبل القراءة: وتهاف هذه المرحلة الإستطلاعية الى مساعدة الطلاب في تذكر ما يعرفونه عن الموضوع من معلومات واستدعائها، بتنثيط معرفتهم،

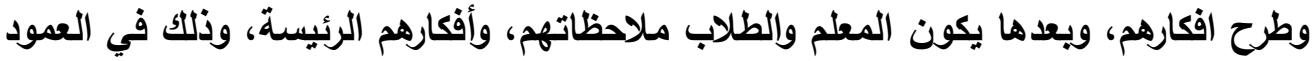

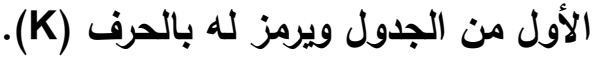
r - الخطوة الثانية من مرحلة ما قبل القراءة: وفيها يبدأ الطلاب بتحديد أهدافهم، التي يُمكن صياغتها على شكل أسئلة تدون في العمود الثاني من الجدول، وما الذي يريدون أن يعرفوه ؟ ويرمز لها بالحرف (W). ؛ - مرحلة القراءة: وفيها يتفص الطلاب كل فقرة من فقرات النص المقروء، فيبدؤون بالتوقع، ويعد قراءة الفقرة ينقحون، ويحدثون ذاكرتهم الخاصة بالموضوع، فضلاً عن توقعاتهم، ومن ثم يكملون قراءتهم، ويعدها يبحثون عن إجابات للأسئلة التي حددت مسبقاً.

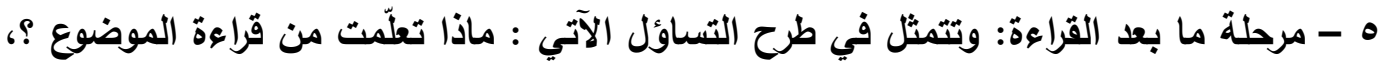
ويُرمز لها بالحرف (L)، ويما أن الأسئلة المطروحة في العمود الثاني وجهت للإجابة عنها، يبدأ الطلاب بتعيئة العمود الثالث من الجدول بمعلومات الإنات إجابات مختلفة تثكل ما تعلموه

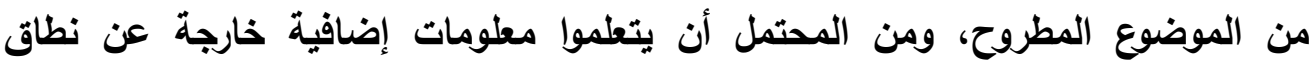
الأسئلة التي طرحت، لذا تدون في العمود الثالث.

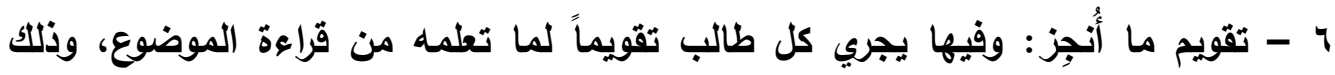
بموازنة محتوى العمود الثالث (ماذا تعلتث؟) بمحتوى العمود الثاني (ماذا أريد أن أتعلم

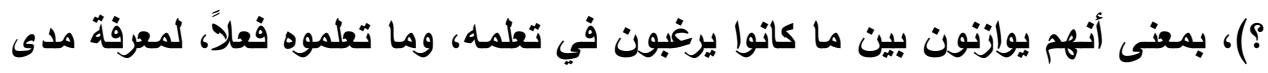


تحقق أهداف الدرس، فضلاً عن تعديل بعض المعتقدات الخطأ إن وجدت قبل التعلم الجديد.

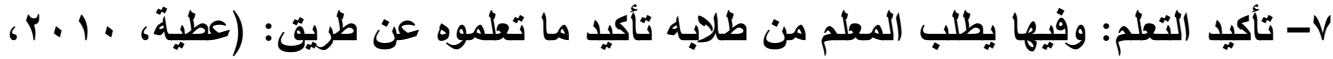

$$
\text { ص (IVD - IVT }
$$

- تقديم عرض شفوي لِما تعلموه.

- تحديد مجالات الإفادة مما تعلّموه، وتطبيقه.

- تلخيص ما تعلموه عن الموضوع.

ووجه لاوزون "Lauzon"(2014)(المعلم إلي إتباع الخطوات التالية عند تنفيذ

استراتيجية(K.W.L))، وهذه الخطوات،هي:

ا. قم بإنشاء جدول (K.W.L) على جهاز كمبيوتز ، ثم قم بالتصوير إلى لوحة بيضاء

تفاعلية ، واستخدم ورق الحامل أو قدم جداول فردية للطلاب.

r. انشر جدول (K.W.L) في الفصل الدراسي طوال مدة الدرس ، بحيث يمكن للطلاب

الرجوع إليه للحصول على إجابات لأسئلتهم.

r. اطلب من الطلاب العودة إلى أسئلتهم لمعرفة ما إذا تم الإجابة عليها أو لا، وإن لم

يكن، اقترح عليهم أن يفعلوا المزيد من البحث والقراءة .

أما وولاندري (Wulandari,2017,p37) ؛(Grabe\&Stoller,2013) فقد لخصوا

خطوات تتفيذ الاستراتيجية في الخطوات الثلاث التالية:

الخطوة الأولى: هي أنشطة ما قبل القراءة: وفي هذه الخطوة يقوم المعلم باستخدام العصف الذهني مع مجموعة من الطلاب لمساعدتهم على التركيز على معرفتهم الحالية عن موضوع الدرس، و يجب أن تؤدي أسئلة المعلم إلى تفكير الطلاب في التفكير بالاستجابة للموضوع ، كما يجب أن يكون علي دراية بالخلفيات الثقافية للطلاب من أجل رصد معرفتهم السابقة حول موضوع الدرس، والغزر من عملية العصف الاهني هذه هو تنشيط المعرفة السابقة لهم لمساعدتهم على فهم ما سيقروئونه في النص،ثم يقوم المعلم بتسجيل استجاباتهم على ملى هوه السبورة أو على أوراق العمل في العمود الأول(K). الخطوة الثانية: هي أنشطة تطوير القراءة: في هذه الخطوة يظور المعلم بشكل طبيعي من تقييم نتائج أنشطة تبادل الأفكار وتصنيفها، كما يطلب من الطلاب تحديد مناطق الجدل و / 
أو الفئات الرئيسية التي تحتوي على معلومات قليلة أو معدومة، والغرض من القراءة هو

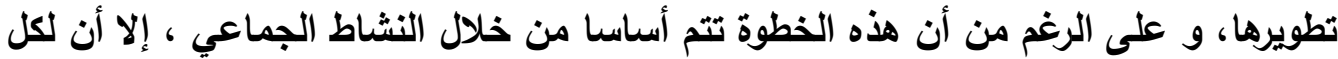
طالب الحرية في كتابة الأسئلة التي يريد معرفتها علي المستوي الثخصي في ورقة العمل بالعمود الثاني (W).

الخطوة الأخيرة:هي بعد القراءة : يطلب المعلم من الطلاب تسجيل نتائجهم في أورلق العمل الخاصة بهم في العمود الثالث(L)، ويتيح لهم خيار كتابة المعلومات إما خلال القراءة أو بعد الانتهاء من القراءة، في النهاية يقيم الطلاب إذا ما كانت أسئلتهم تم الرد على عليها من خلال قراعة النصوص أم لا. وأضاف (2017,p38) Wulandari أنه إذا المتاج الطلاب معلومات إضافية حول الموضوع ، ينبغي أن يوجههم المعلم ويرشدهم إلى مصادر تعلم أخرى لإثراء معلوماتهم. كما يستطيع المعلم تطبيق هذه الاستراتيجية بشكل فاعل في الموقف الصفي من خلال

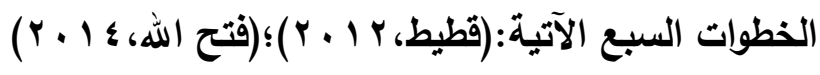

أولاً: يطلب المعلم من طلبته أن يُسّطروا الورقة الأولى من كل درس في دفاترهم (Sheet) الورق والطباعة. ويبن المعلم للطلبة أن يُسّطروا جدول(K.W.L) في دفاترهم. ثانياً: يقوم المعلم في بداية الحصة بكتابة أو عرض عنوان الدرس أو الموضوع أو المفهوم

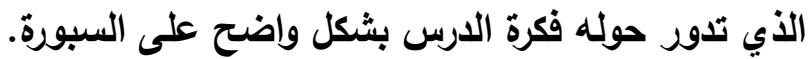
ثالثاً: توجيه الطلبة في بداية كل حصة نحو تعبئة العمودين (K) و(W) حول الموضوع الذي تم كتابته على السبورة. وترك العمود الثالث (L) لتعبئته في نهاية الحصة. رابعا: يناقش المعلم الطلبة حول ما كتبوه في ورقة(KWL Sheet) عن ما يعرفونه أو ما يريدون أن يعرفوه عن الموضوع.

خامسا: يقوم المعلم بتقديم الموضوع حسب الطريقة التي يراها مناسبة للطلبة. سادسا: في نهاية الدرس ويعد تقديمه كاملاً ، يوجه المعلم الطلبة لتعبئة العمود الثالث (L) (KWL Sheet).في ورقة سابعا: مِاقشة الطلبة فيما تعلموه، وما كتبوه على ورقة (K.W.L Sheet) ، وهي بمثابة تغذية راجعة للمعلم عن الموقف الصفي كاملاً. 
وأثشار Adeel (2015) أنه لكي تنفذ استراتيجية(K.W.L) بنجاح يجب أن تنظر في

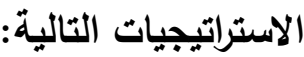

تعمل استراتيجية (K.W.L) على أفضل نحو عندما يكون لاى الطلاب بعض

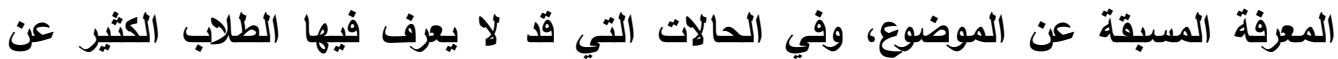
الموضوع ، يجب أن يكون هناك بعض الأنثطة الأولية التي تحفز وتهيأ الطلاب نحو الموضوع ، مثل الفيديو أو الفصل الدراسي ،مناقثة ، أو مهمة بحث، أما في الحالات التي لهي يكون فيها معرفة مسبقة قليلة عن هذا الموضوع لدي الطلاب، يكون من المفيد صياغة سؤال محدد لهم للتركيز على الموضوع. يمكن للطلاب ملء جداول(K.W.L) بمفردهم، في أولق العمل، كما يمكن للمدونة في كل مجموعة أن تكتب ما يعرفه كل طالب عن الموضوع وما يريد معرفته وما تعلمه اولهات .(Logsdon, 2018)

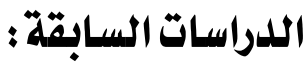

هدفت دراسة عرام(Y Y Y Y) إلي معرفة أثر استخدام استراتيجية (K.W.L) في اكتساب

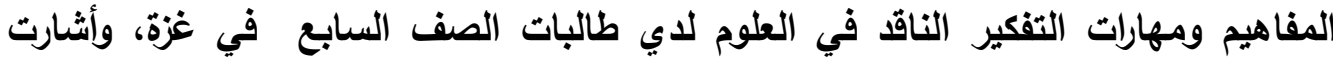
نتائج الدراسة إلي وجود فروق ذات دلالة إحصائية عذد مستوي دلالة (ه . , •) بين متوسطات فئات درجات طالبات المجموعة التجريبية عن درجات المجموعة الضابطة في اختبار المفاهيم العلمية، وكذلك اختبار مهارات التفكيرالناقد لصالح المجموعة التجريبية.

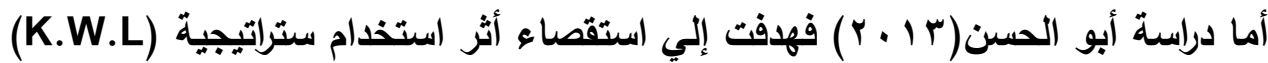
في تدريس الرياضيات علي التحصيل الدراسي لطلاب الصف السادس الأساسي بالمنطقة

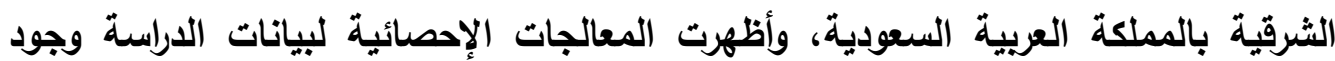
فروق ذات دلالة إحصائية في التحصيل الدراسي لكل من الطلبة والطالبات تعزي إلي استخام استراتيجية(K.W.L).

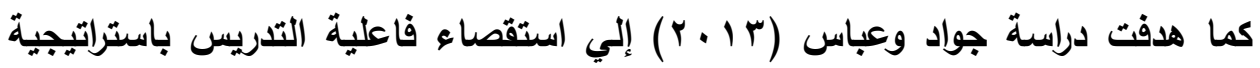
الجدول الذاتي(K.W.L.H) في تنمية مهارات التفكير العلمي لاي طالبات الصف الثاني

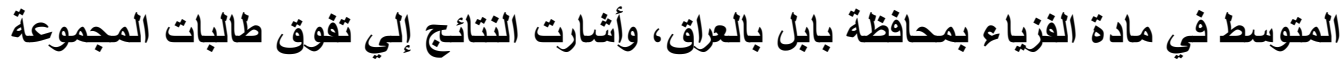


التجريبية التي درست باستراتيجية(K.W.L) علي طالبات المجموعة الضابطة في اختبار مهارات التفكير العلمي.

في حين هدفت دراسة أرهيف و إبراهيم (10 + ب) إلي تعرف أثر استخدام استراتيجية (K.W.L) إلي فاعلية استراتيجية (K.W.L) في تنمية الوعي الصحي لاي الطلبة.

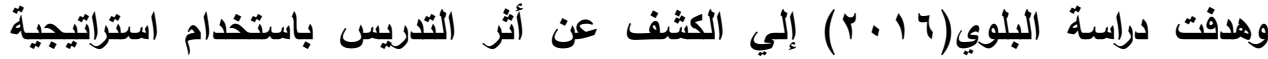
(K.W.L) تطبيقات إحصائية في العلوم الإنسانية، وأثشارت النتائج إلي وجود فروق ذات دلالة إحصائية بين المجموعتين(التجريبية والضابطة) في التطبيق البعدي للاختبار التحصيلي في مادة التطبيقات إحصائية في العلوم الإنسانية، لصالح المجموعة التجريبية، كما أثشارت النتائج إلي عدم وجود فروق دالة إحصائيا بين متوسط درجات المجموعة التجريبية في التطبيق البعدي والمؤجل للإختبار التحصيلي.

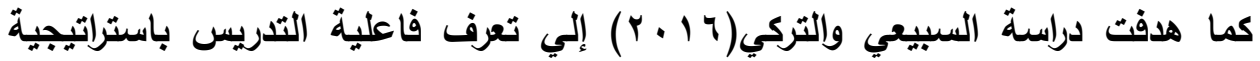
في تصويب أنماط القهم الخطأ في بعض مفاهيم مقرر الحاسب الآلي لاي طالبات الصف الأول الثانوي، وأثثارت النتائج إلي وجود فروق ذات دلالة احصائية بين متوسطي درجات المجموعة التجريبية والضابطة في القياس البعدي للإختبار لصالح المجموعة التجريبية. أما دراسة (2016) Zouhor, Bogdanovic and Segedinac فقد هدفت إلي إختبار تأثير استراتيجية(K.W.L) علي مهارات ما وراء المعرفة وتحصيل الفيزياء لاي طلاب المرحلة الإبتدائية، وقد تم تطبيق استبيان مهارات ما وراء المعرفة واختبار معرفي في الفيزياء قبليا ويعديا علي مجموعتي الدراسة(الضابطة والتجريبية) علي الجنسين(ذكور وإناث)، وأشارت النتائج إلي وجود فروق ذات دلالة إحصائية بين درجات المجموعة التجريبية في التطبيق القبلي والبعدي ( للإستبانة والإختبار) لصالح التطبيق البعدي،وتوصلت الدراسة لأهمية استخدام (K.W.L) في تدريس الفيزياء. 
وهدفت دراسة" (Wulandari (2017) " إلي تعرف أثر استخدام استراتيجية (K.W.L) علي تنمية القراءة الشمولية في اللغة الإنجليزية لطلاب الصف الثامن، وأظهرت النتائج أن هناك فرق كبير في فهم الطلاب للقراءة قبل ويعد استخدام استراتيجية تعرف المعرفة

وتعلمها(K.W.L).

باستقراء الدراسات السابقة لوحظ عدم وجود دراسة واحدة بينهم استهذفت دراسة استراتيجية)(K.W.L) في مقرر طرق تدريس الاقتصاد المنزلي.

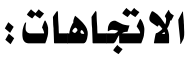

تعريف الاتجاهات:

تعتبر الاتجاهات من المصطلحات المهمة ؛ لذلك تعددت وتنوعت تعريفاتها وفقا

لمجال دراستها، ومن هذه التعريفات ما يلي:

تتفق الأدبيات علي تعريف الاتجاه بأنه" الموقف الذي يتخذه الفرد أو الإستجابة التي يبليها إزاء شيع معين أو حلث معين او قضية معينه، إما بالقبول أو الرفض نتيجة مروره

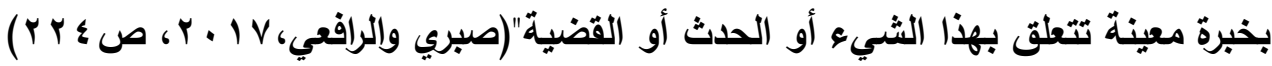

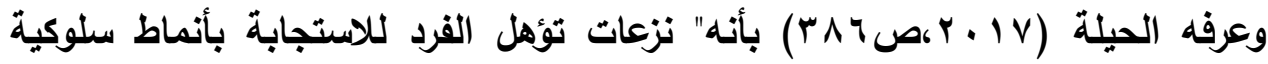
محددة نحو أثخاص أو أفكار أو حوادث أو أوضاع أو أشياء معينة، تؤلفف فيما بينها نظاما معقداً تتفاعل فيه مجموعة كبيرة من المتغيرات المتنوعة".

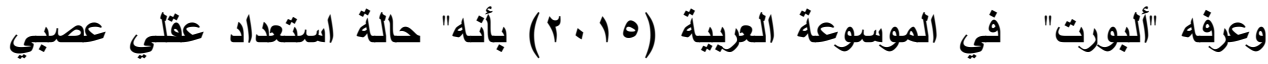
ناتجة عن الخبرات الشخصية للفرد،وتعمل علي توجيه إستجاباته للمواقف والموضوعات المختلفة".

مكونات الاتجاهات :

أشارت العديد من الدراسات أن لاتجاهات ثلاثة مكونات،هي:

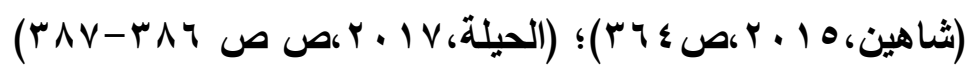


1-المكون المعرفي: وهو المعلومات والمعارف التي تنظوي عليها وجهة نظر صاحب الاتجاه، وكلما زادت معرفته حول موضوع الاتجاه، وكانت دقيقة وصحيحة؛ كلما كان اتجاهه مبنيا علي أسس سليمة.

Y-المكون الوجداني أو العاطفي: و يرتبط بمشاعر الفرد وإنفعالاته التي تؤثثر في استجاباته المؤيدة والمعارضة والمحايدة، وليس بالضرورة أن يكون منطقيا. r-المكون السلوكي أو الأدائي: وهو الفعل الذي يقوم به الفرد ويشير إلي اتجاهه، ويعد مؤشرا جيدا علي اتجاهه الذي تحدده سلوكياته المرتبطة بالمكونيين المعرفي والوجداني.

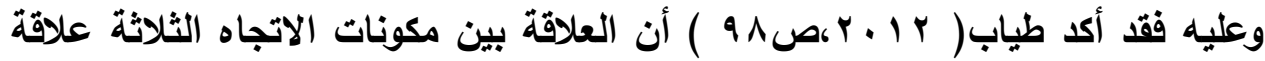
تكاملية وسبيية، ولا يمكن الفصل بينها عند إستجابة الفرد لموقف ما أو موضوع ما، غير أن المكون الوجداني يظل من أكثر المكونات أهمية في تكوين الاتجاهات. يتضح مما سبق أن الاتجاهات تتكون عن طريق الخبرات والتجارب الشخصية السابقة في المجالات المعرفية والوجدانية والسلوكية، وتؤدي إلي السلوك المستقبلي. خصائص الاتجاهات:

اتقق العديد من الباحثين التريويين علي أن الاتجاهات تتمتع بالخصائص

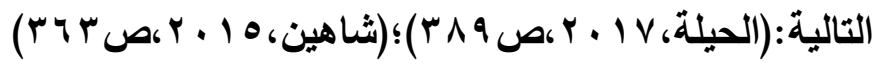
- الثبات والاستقرار النسبي- تعتبر موجهات لسلوك الفرد والجماعة - مكتسبة ومتعلمة- قابلة للتطوير والتغيير - تتدرج في التأييد سلبيا وإيجابياً- ترتبط بثقافة المجتمع تختلف من مجتمع إلي آخر - تتضح من خلال سلوك الفرد- يتم من خلالها التنبؤ باستجابات الفرد لبعض المواقف - تتكون من ثلاثة مكونات هي:(المعرفي-الوجداني- السلوكي)،ويؤثر بعضها في بعض - قابلة للقياس والتقويم من خلال ملاحظة السلوك. الاتجاه نحو مقرر طرق تلدريس الاقتصاد المنزلي، أهميتها : الاتجاه نحو طرق التدريس مهما لكلا من:(الطالبة والمعلمة)،وذلكك علي النحو

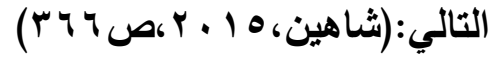
- تساعدهما علي التقدم في الجواتب المعرفية المتضمنة بالمقرر والاستمتاع بدراسته. - تحثُهما علي المثابرة والدافعية وحب الاستطلاع. - تحقق التفاعل الايجابي بينهما. 
دراسات سابقة عن الاتجاه نحو طرق التدريس :

نظرا لأهمية الاتجاهات للمعلمة والطالبة علي حد سواء،ققد اهتمت بعض الدراسات

بتتاولها بالبحث والاراسة،وفيما يلي عرضا لهذه الدراسات:

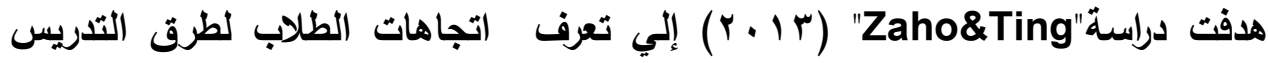
المستخدمة في أغلب جامعات انجلترا واتجاهاتهم نحوها، وتوصلت نتائج الدراسة إلي وجود فرق كبير بين اتجاهات طلاب المنطقة الغربية والثرقية في معرفتهم لطرق التدريس المستخدمة في الجامعات البريطانية، كما أشارت النتائج أنه لا توجد علاقة إيجابية أو سلبية بين معرفة الطلاب لطرق التدريس وإتجاهاتهم نحوها. بينما هدفت دراسة الثويني(10) ب ب إلي إستقصاء أثر التدريس المصغر في تتمية المهارات التدريسية لدي طلاب التربية الميدانية بجامعة حائل واتجاهاتهم نحوها، وتوصلت إتل النتائج إلي أن اتجاهات الطلاب المعلمين نحو استخدام التدريس المصغر كانت إيجابية. في حين هدفت دراسة شاهين(10) ب إلي تعرف اتجاهات طلاب الجامعة الإسلامية نحو مقرر طرق التدريس والتربية العملية ومهنة التعليم في ضوء بعض المتغيرات، وأشثارت النتائج أن اتجاهات الطلاب جاءت إيجابية ومرتفعة، كما توصلت إلي وجود علاقة إرتباطية موجبة ذات دلالة إحصائية بين اتجاه الطلاب نحو مقرر طرق التدريس والتربية العملية ، ومهنة التعليم.

\section{مقررطريقة تلدريس خاصة( ) ( )}

طريقة التدريس هي الجانب التنفيذي لأي مقرر دراسي فإذا كان هناك مستوي تخطيطي للمقر، فإن له مستوي تتفيذي يتمثل في طرق التدريس واستراتيجيات (تمام

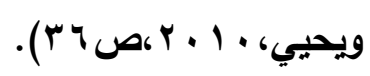

و مقرطرق تدريس خاصة (1) من مقررات الاعداد التربوي للطالبة المعلمة بكلية التصاميم والاقتصاد المنزلي، حيث يرس لطالبات الفرقة الثالثة بواقع ساعتين نظريتين، كما يعتبر متطلبا مهما لمقرر طرق تدريس خاصة(r) (جامعة القصيم ، دليل الطالب، ، 10 ب ب).

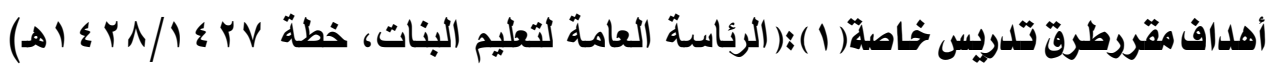
يهرف هذا المقرر إلى اكساب الطالبات/المعلمات القدرة علي:

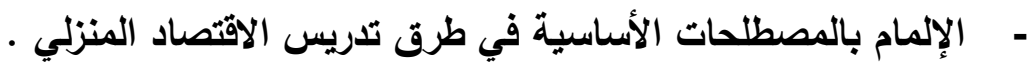


- - تحديد أهداف الدرس وصياغتها بطريقة صحيحة . - التخطيط الصحيح للتدريس . - اختيار الأنشطة التعليمية المناسبة لطرق التدريس المختلفة.

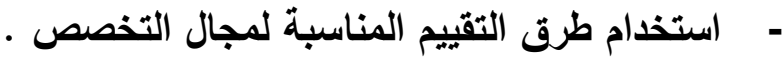
- ريادة الصف وضبطه.

خطوات تدريس مقررطرق تدريس خاصة( ) الاقتصاد المنزلي وفقا لاستراتيجية(K.W.L)؛ لكي تنجح معلمة التربية الأسرية (الاقتصاد المنزلي) في تطبيق هذه الاستراتيجية بالتدريس عليها إتباع الخطوات التالية:

1 - التقايم لموضوع الارس،ومن ثم استنباط عنوانه من الطالبات وكتابته علي السبورة. r - تذكير الطالبات باستراتيجية (K.W.L)، وخطواتها، ولهذا لم تكتفي الباحثة بأولق العمل، بل تم إدراجها بكتيب الطالبة.

r- تقسيم الطالبات إلي مجموعات عمل أو تعلم تعاوني حسب متطلبات الموقف التعليمي. ع - توجيه الطالبات إلي استخدام أوراق العمل التي يتضمنها كتيب الطالبة، وتتضمن جداول

$$
\text { (K.W.L) }
$$

ه - استخدام الكتاب المقرر ويعض المراجع الثانوية المساندة، كما وردت بتوصيف المقرر.

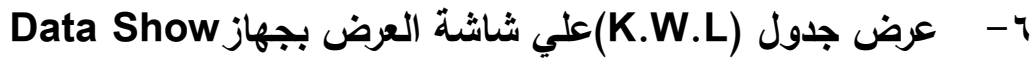
- - - تقسيم موضوع الدرس إلي مفاهيم وأفكار رئيسية. ^- سؤال الطالبات عن ماذا يعرفن عن المفهوم الأول من الارس، وهكذا مع كل عناصر ومفاهيم الدرس. 9- تكتب المعلمة أو إحدي الطالبات المعارف السابقة لاي الطالبات علي السبورة في العمود الأول (K) ، ثم تطلب منهن نقلها وتسجيلها في أوراق العمل، وهكنا مع كل عناصر الدرس أو الموضوع، كما يمكن للطالبات تعبئة جداولثهن في أورلق العمل بثكل

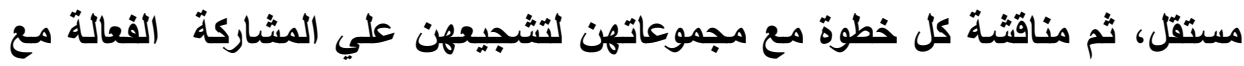
الزميلات، وزيادة فهمهن. 
• 1 - تسأل المعلمة الطالبات عن ما الذي يرغبن في تعلمه عن الفكرة الأولي أو المفهوم

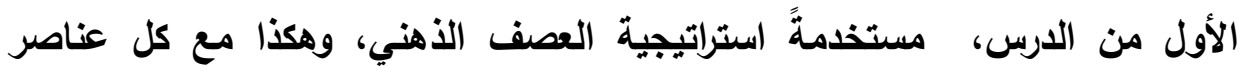
الارس.

1 - 1 - تكتب المعلمة أو إحدي الطالبات الأسئلة علي السبورة في العمود الثاني(w) ،ثم تطلب من الطالبات نقلها وتسجيلها في أورلق العمل، وهكذا مع كل عناصر الارس. r ا- تبدأ المعلمة في شرح الدرس مستخدمة طرق التدريس المناسبة، والمساندة لاستراتيجية (K.W.L) ) مثثل: المحاضرة التفاعلية، والمناقشة،العصف الذهني، ويعض أنماط التعلم التعاوني، والنشط، كما تستعين بعروض البوريوينت، فضلا عن الاستعانة بالكتب المقررة والثبكة العنكبوتية كمصادر للتعلم. rا - تسأل المعلمة الطالبات عن ماذا تعلمن من وعن موضوع الدرس، وتكتب الإجابات

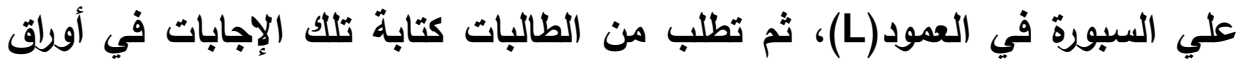
العمل، وهكذا مع كل مفاهيم الدرس. ع ا- تقام المعلمة تغذية راجعة للطالبات عن إجاباتهن للأسئلة. ه ا- توجه المعلمة الطالبات لعقد مقارنات بين العمود الأول والعمود الثاني، وكذلك العمود الثاني، والعمود الثالث، وتحديد المعومات الإضافية التي لم يتوقعن دراستها، وكذلك توجيه الأسئلة التي لم تثم الإجابة عنها كأسئلة بحثية. 7 ا - تتأكد المعلمة من تعلم الطالبات، حيث تطلب منهن تقديم عرض شفوي عما تعلموه، ومجالات تطبيقه وتلخيص ما تم تعلمه في أورلق العمل. دور معلمة التربية الأسرية في استراتيجية (K.W.L )؛ تؤدي المعلمة في هذه الاستراتيجية دوراً مختلفا عن الدور التقليدي القائم على الإلقاء

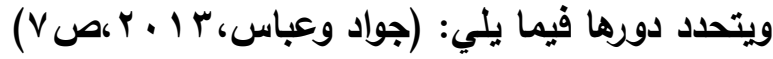
1 - الكشف عن المعارف السابقة لاي الطالبات كأساس للتعلم الجديد. r - ضبط البيئة التعليمية، وإدارة مجموعات النقاش. r- تنظيم معارف الطالبات ضمن مخطط الاستراتيجية. ع - محاورة الطالبات لتوليد أسئلتهم وتحفيز تفكيرهن. ه- توجه الطالبات نحو ما ينبغي لهن فهمه، والاحاطة به. 
צ- تقويم أداء الطالبات، ومدى تحقيقهن للأهداف المرجوة من الدرس. V- يوفير الفرص اللازمة لتشجيع الطالبات على التعلّم الأتي، والإعتماد على أنفسهن

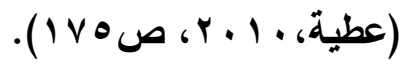

^- استخدام العصف الذهني لحفز عقول الطالبات، لتوليد الأسئلة التي يرغين في تعلمها

$$
\text { حول الموضوع (فتح الله، \& } 1 \text { • ب). }
$$

وعلي أية حال فإن المعلم هو الأساس في العملية التريوية، ونجاحها في تحقيق أهدافها، والعامل الإيجابي الأي يجسدها، وينقلها من مجال المطامح أو التطلعات إلي حيز

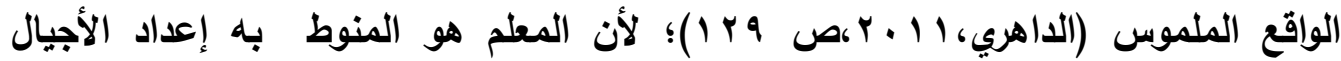

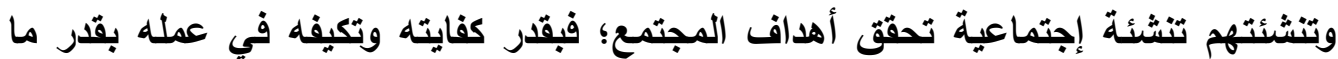

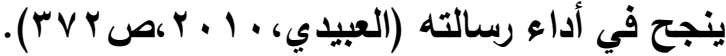

$$
\begin{aligned}
& \text { دور الطالبة/المعلمة في استراتيجية(K.W.L): }
\end{aligned}
$$

يتحدد دور الطالبة وفق هذه الاستراتيجية في المحاور الآتية: (منهل الثقافة

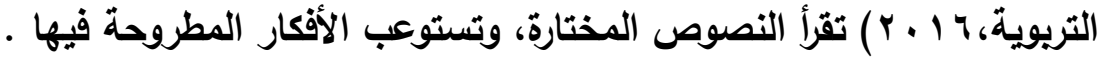

1 - تطرح الأسئلة التي تلبي حاجاتها المعرفية المبنية على معرقتها السابقة . r - تمارس التفكير المستقل في القضايا والأفكار التي يدور حولها النص . r- تصنف الأفكار الواردة في النص إلى محاور أساسية وفرعية . ع - تتدرب على ممارسة التفكير التعاوني مع باقي أفراد المجموعات . ه- تصوب ما رسخ في بنائها المعرفي السابق من معارف وحقائق غير صائبة(نايف

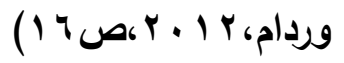

צ- تقرر ما تعلمته بالفعل من النص وتحاول أن يستمر في البناء المعرفي لايها من

$$
\text { خلال توليد أسئلة جديدة. }
$$

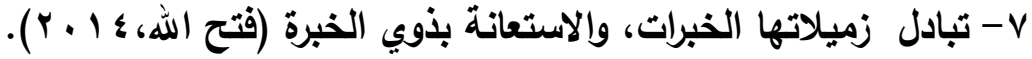

منهج البحث وإجراءاته :

أولاً : منهج البحث و التصميه التجريبي: اعتمدت الباحثة المنهج شبه التجريبي لأنه المنهج الملائم لتحقيق هلف البحث. 
التصميم التجريبي:أتبعت الباحثة تصميم المجموعتين المتكافئتين وهما (التجريبية والضابطة) و هو من التصميمات التجريبية التي يتم فيها حصر المتغيرات الخارجية ذات الأثرعلي التجرية ماعدا المتغير المستقل، ثم تعرض المجموعتان لاختبار قبلي، ثم تخضع المجموعة لأمئ

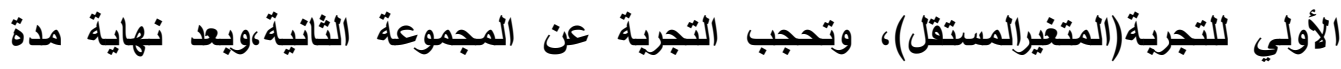
التجرية تعرض المجموعتان لاختبار بعدي، بهدف معرفة أثر التجرية علي المجموعة الأولي)

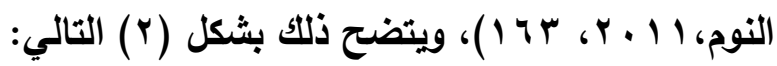

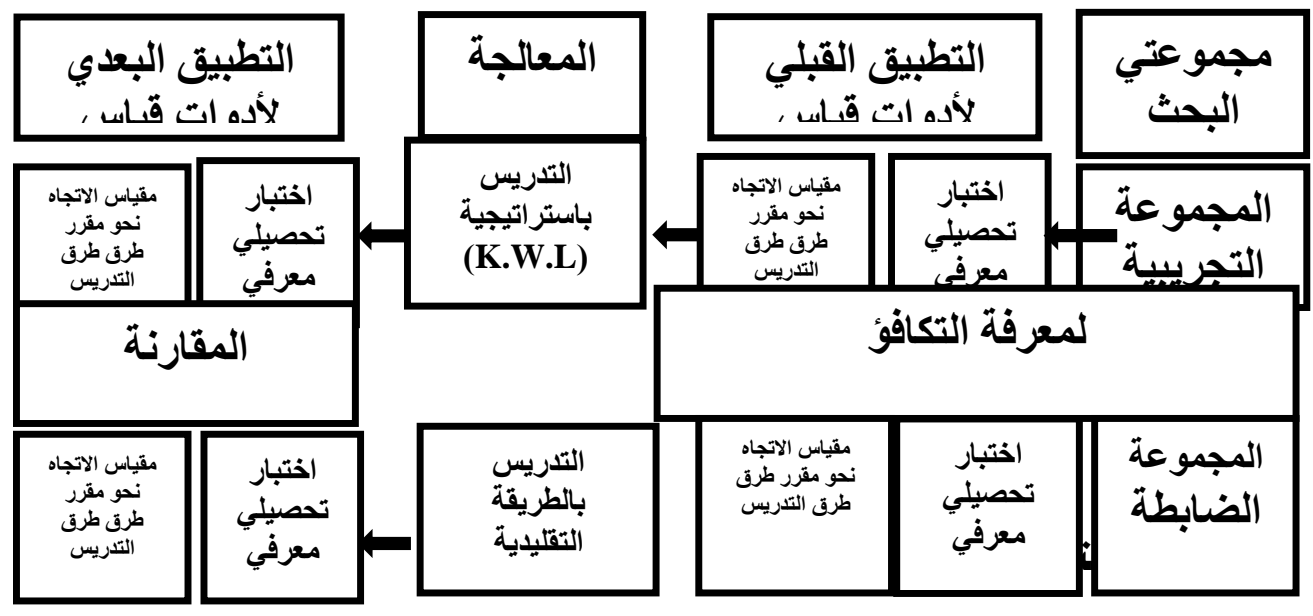

شكل ( 1) التصميم التجريبي للبحث الحالي

\section{ثانبا : مجتمع البحث وعينته :}

تمثل مجتمع البحث الحالي في طالبات الفرقة الثالثة بقسم تصميم الأزياء البالغ عددهن(^V) طالبة موزعة علي ثلاث شعب، ومن ثم تم إختيار عينة البحث بطريقة مقصودة، ووقع الاختيار علي أصغر شعبة لتمثل العينة الإستطلاعية، والثُبتين الأخيرتين مثلتا المجموعتين( التجريبية والضابطة)، ويعد إستبعاد الطالبات المنسحبات من الثعب، الإسبة وكذلك الطالبات غير الجادات أصبح عدد طالبات المجموعة التجريبية(rr) طالبة، و عدد طالبات المجموعة الضابطة (r Y طالبة أيضا. 
ثالثا : المواد التعليمية وشملت ما يلي: دليل المعلمة( عضو هيئة التدريس ) : قامت الباحثة بإعداد دليل المعلمة مع مراعاة ما يلي: - الإطلاع علي الأدبيات التريوية والدراسات السابقة ذات مرات الصلة. - تحديد موضوعات مقرر طرق تدريس خاصة(1) الإسي يمكن تدريسها وفقا لاستراتيجية (K.W.L) - إعادة صياغة بعض موضوعات مقرر طرق تدريس خاصة(1) وفقا لاستراتيجية (K.W.L) - نبذة عن استراتيجية (K.W.L). - إششادات للمعلمة تساعدها علي تدريس المقرر باستراتيجية (K.W.L). - خطوات التدريس باستراتيجية (K.W.L). بشكل عام.

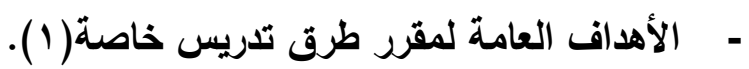
- التوزيع الزمني لتدريس موضوعات المقرر . - خطة تدريس كل موضوع من موضوعات المقرر المختارة، وتضمنت ما يلي:

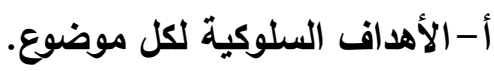
ب- الأدوات والوسائل التعليمية، ومصادر التعلم المتطلبة لتنفيذ كل موضوع. ت - خطة سير التدريس وإجراءات التنفيذ.

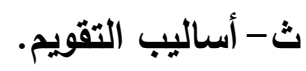

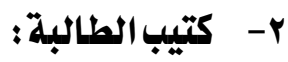

قامت الباحثة بإعداد كتيب للطالبات وفقا لاستراتيجية (K.W.L) يتضمن أورلق العمل لكل موضوع ؛ حتي يتسني لهن فهم خطوات الاستراتيجية في أثناء التدريس، وكذلك معرفة دورهن خلال التدريس، وقد تضمن الكتيب ما يلي: تقديم للاستراتيجية، وتعريفها،أهدافها،

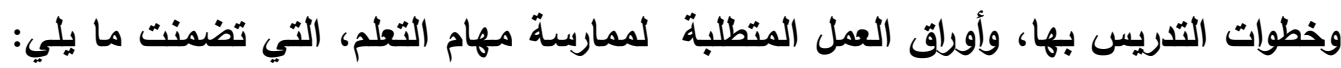
عنوان الدرس، أهدافه ، والأنشطة التعليمية المصاحبة لخطوات الاستراتيجية، ومخطط فارغ لحقول الاستراتيجية، تلخيص ما تم تعلمه، وتقويم ما تم تعلمه. 
الضبط العلمي لللدليل والكتيب:

بعد الانتهاء من إعداد دليل المعلمة وكتيب الطالبة تم عرضهما علي مجموعة من

السادة المحكمين المتخصصين في المناهج وطرق التدريس عامة وطرق تدريس الاقتصاد المنزلي خاصة ملحق (1) ، وذلك بهدف استطلاع أرائهم ملحق (Y) حول ما يلي: مناسبة

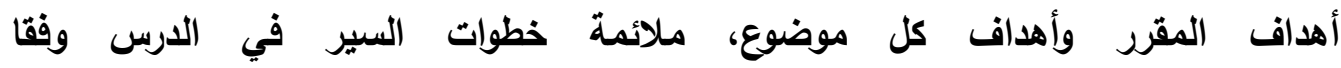
لاستراتيجية (K.W.L). ،مناسبة الأنثطة التعليمية والوسائل التعليمية لتحقيق الأهداف، مناسبة أساليب التقويم المتبعة لمستوي الطالبات، وقد أقر السادة المحكمين صلاحيتهما

للتطبيق، ويذلك أصبح الاليل والكتيب جاهزين للتطبيق. ملحق (ب)، ملحق ( ( ) رابعا :إعداد أدوات القياس، وشملت ما يلي: إعداد إختبار تحصيلي معرفي:

لإعداد وتصميم الاختبار أتبع البحث الحالي الخطوات التالية:

1- ت تحليل هدف الإختبار:

صمم هذا الاختبار بهدف قياس التحصيل المعرفي لدي الطالبات عينة البحث وفقا لمستويات بلوم المعرفية.

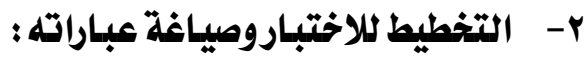
أ- اختيار نوع الاختبار:لتحديد نوع الإختبار راجعت الباحثة ما يلي: العديد من المراجع والدراسات السابقة التي استخدمت اختبارات للتحصيل المعرفي وجاء

الاختبار من نوع الإختبارات الموضوعية. ب- صياغة عبارات الاختبار( وصف وتصميم الأختبار ) : تكون الاختبار من جزأين هما: - الجزء الأول: أسئلة الاختيار من متعددهوهو من أكثر الاختئة الاختبارات الموضوعية

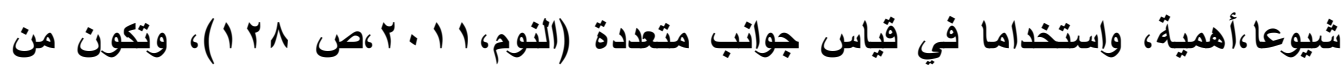

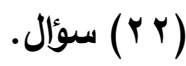
ـ الجزء الثاني: أسئلة الصواب والخطأ وتم اختياره لقياس درجة استيعاب الطالبات للحقائق والمفاهيم المتضمنة بالمقرر ،وتكون من(1 ا ) سؤال. 
جـ - تمليمات الاختبار:

تم وضع تعليمات الاختبار في الصفحة الأولى من كراسة الأسئلة والإجابة وروعي فيها أن تكون واضحة ودقيقة، وذكر مثال لتوضيح كيفية الإستجابة.كماروعي أيضاً أن يكون طول الاختبار ملائماً، حتى لا تشعر الطالبات بالملل أو الإجهاد فيؤثر ذلك على ودئ أدائهن.

د - طريقة تصحيح الاختبار:

تم تصحيح الاختبار بإعطاء درجة واحدة للإجابة الصحيحة وصفر للإجابة غير الصحيحة مـع عدم وجود درجات بين الصفر والتواحد الصحيح وإجمالي الدرجات يساوي الدرجة

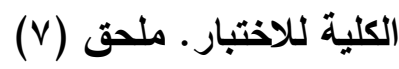

r- عرض الإختبار في صورته المبلئية على السادة المحكمين :ملحق (0 ) تم عرض الاختبار على بعض السادة المحكمين في مجال المناهج وطرق التدريس وعلم النفس والقياس والتقويم التريوي؛ بهدف التحقق من صدق محتوى الإختبار وسلامة عباراته وملائمته لعينة البحث، و قد تم تعديل إعادة صياغة بعض الأسئلة على ضوء إقتراحات

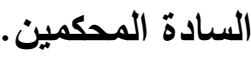
ع- التجربة الاستطلاعية للاختبار: طبق الاختبار في صورته الأولية على العينة الإستطلاعية "غير عينة البحث" من

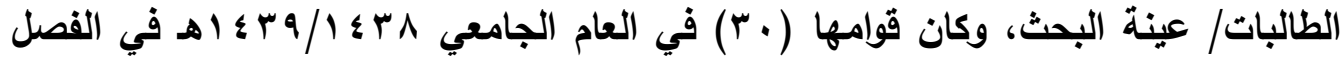
الدراسي الأول وهدفت التجرية الإستطلاعية إلي الحصول على البيانات التالية: صدق الإختبار: تم حساب الصدق بالطرق التالية:

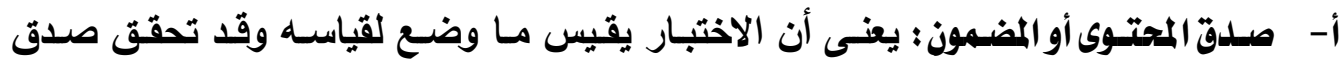
محتوى الاختبار من خلال: - إعداد جدول مواصفات الاختبار الذي يساير عمليات إعداد الاختبار خطوة بخطوة ويصف الإن الاختبار ويحدد نوعه.

- تحديد عدد الأسئلة التي سيتم إعدادها والمرتبطة بكل هدف وكل موضوع، وهو مهم في بناء الاختبار لأنه يؤمن صدق الاختبار، ويتضح ذلك بجدول (1) التالي: 


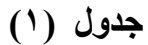

مواصفات الاختبار التحصيلي المعرفي لمقرر طرق تدريس خاصة(1)

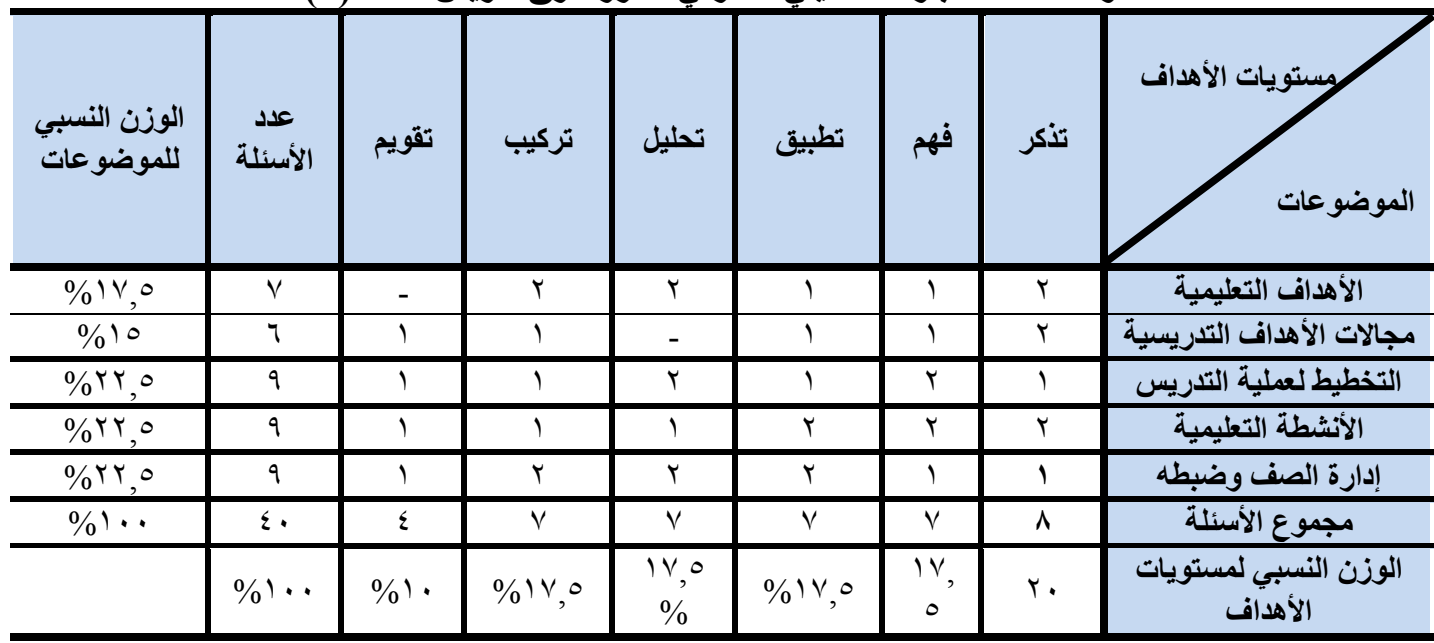

ب - الصدق الظاهري: وتحقق من خلال إجماع السادة المحكمين على أن كل أسئلة الاختبار تغطي موضوعات مقرر طرق تدريس خاصة( (1).

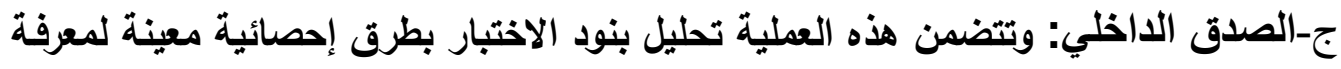

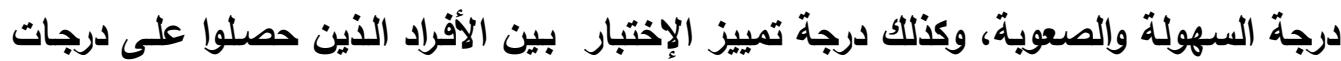

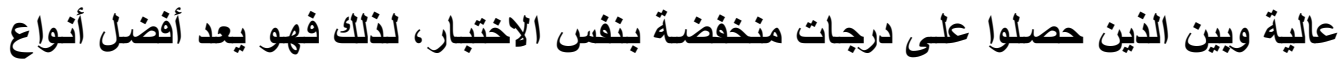

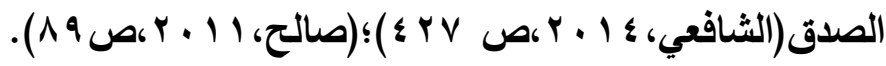
لذلك قامت الباحثة بتحليل بنود الاختبار لضبطه إحصائيا من خلال حساب ما يلي: - حساب معاملات سهولة وصعوبة الاختبار: تم حساب معاملات السهولة والصعوية لأسئلة الإختبار، وقد تراوحت هذه المعاملات مـا بين

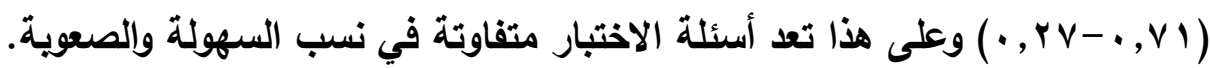
- - مسابات معاملات التمييز لكل لمفردات الإختبار: -

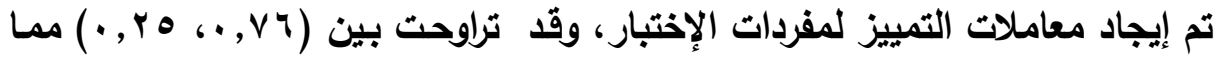
يدل على أن أسئلة الاختبار كلها مميزة. - - - حساب معامل ثبات الاختبار: 
لحسـاب معامـل ثبات الاختبـار تـم استخدام معامـل ارتبـاط "سبيرمان ويراون"للتجزئسة

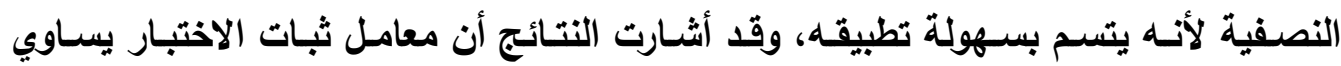
ب 9 . - وهي درجة عالية ومقبولة من الثبات. - - تحلديل الزمن اللازم لتطبيق الاختبار: في ضوء ما أسفرت عنه نتائج التجريب الاستطلاعي للاختبار تم تعديد زمن الاختبار باستخدام معادلة حساب زمن الاختبار، وذلك بحساب متوسط الزمن الأي استغرقته

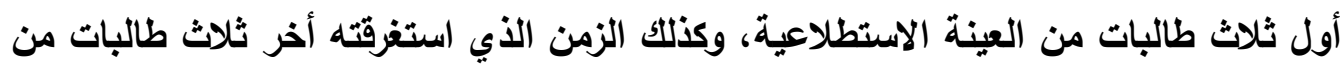
العينة الإستطلاعية، و ووجد أن متوسط الزمن اللازم للإجابة يساوي (ه ب) دقيقة. 0- الصورة النهائية للاختبار: بعد إجراء التعديلات السـابقة على الاختبار؛ أصبح الاختبار في صورته النهائية

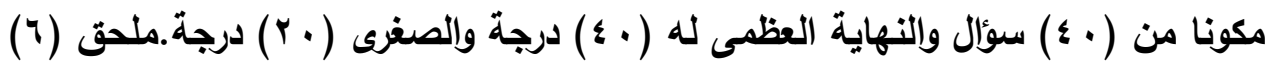
ثانيا : إعداد مقياس الاتجاه نحو مقررطرق تدريس خاصة( ( ) : مر إعلداد المقيساس بـالخطوات التاليةة: مراجعة بعض الكتب والدراسـات التي تناولت مقاييس

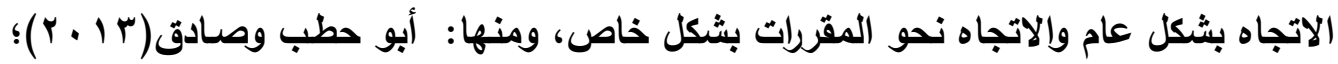

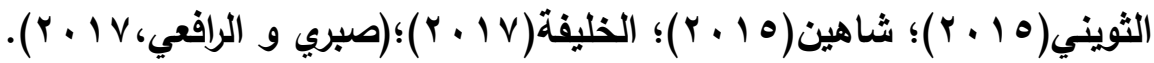

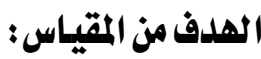
هدف المقياس إلي قياس اتجاه الطالبات عينة البحث نحو مقر طرق تدريس

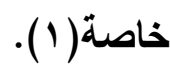
تحليل محاور المقياس ونوعه : 1- المحور الثاني: الاستمتاع بدراسة المقرر (rr) عبارة.

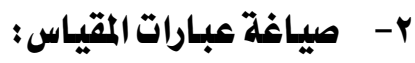
تم صياغة عبارات المقياس في ضوء إطلاع الباحثة على بعض البحوث والاراسات

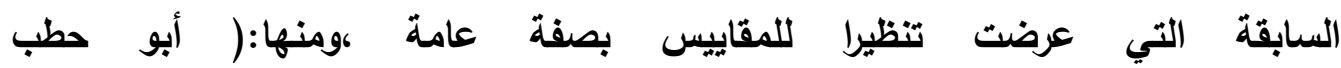




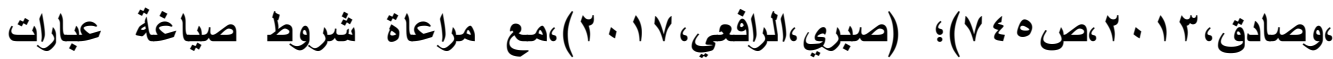
المقياس، والجدول (Y) التالي يوضح عدد ونوعية عبارات كل محور من محاور المقياس مراه جأول (r)

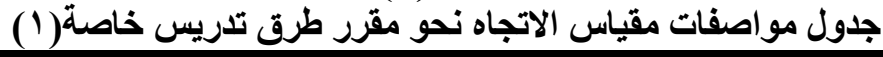

\begin{tabular}{|c|c|c|c|}
\hline إجمالّي عدد العبارات & العبارات السلبية & العبارات الايجابية & المقياس \\
\hline rr & $\begin{array}{l}-r 1-r r_{-} \mid V_{-} q_{-} V_{-} \theta \\
\varepsilon 1, r q-r V_{-} r r_{-} r q\end{array}$ & $\begin{array}{c}-\left|q_{-}\right| \theta_{-}\left|r_{-}\right| 1-V_{-} \mid \\
\varepsilon r_{-} \theta_{-} r V_{-} r \theta_{-} r \mid\end{array}$ & الأول \\
\hline$r$. & $\begin{array}{c}-r \varepsilon-1 \varepsilon-1 r_{-} \mid \cdot-\tau_{-} \varepsilon \\
\varepsilon \cdot-r q_{-} r \varepsilon_{-} r .\end{array}$ & $\begin{array}{c}r r_{-} r_{-}\left|\Lambda_{-}\right| \gamma_{-} \Lambda_{-} r \\
\mu_{-} r_{-} \Lambda_{-} r{ }^{2}\end{array}$ & الثاني \\
\hline$\varepsilon Y$ & YI & YI & مبار المحورت \\
\hline
\end{tabular}

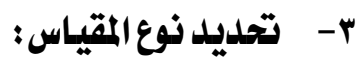

استخدمت الباحثة طريقة ليكرت"Likert" في تقدير درجات المقياس، لأنه من أشهر مقاييس الاتجاهات، وتمتاز بالسهولة النسبية في التصميم والتصحيح والدقة والثبات، وجاعت لهي لهات عبارات المقياس على مقياس ثلاثي متدرج (موافقة -غير متأكدة-غير موافقة) لأنها أكثر ملائمة للطالبات عينة البحث ولا تستغرق وقتاً طويلاً فى الاستجابة على عبارات المقياس(أبو

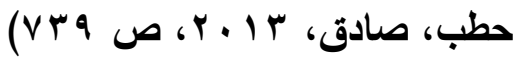
ع - تعليمات المقياس:حرصت الباحثة على أن تكون تعليمات المقياس واضحة للطالبات. عرض المقياس على السادة المحكميز : بعد الاتتهاء من إعداد المقياس فى صورته الأولية قامت الباحثة بعرضه على

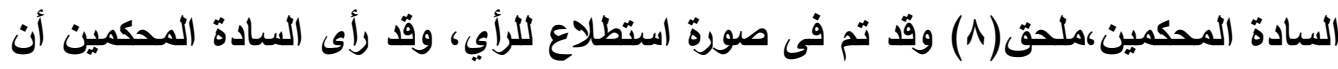
عبارات المقياس مناسبة لمحتوى المقرر ومناسبة للطالبات عينة البحث، كما أن العبارات سهلة الفهم وواضحة المعنى بالنسبة للطالبات، كما اتفق أغلب السادة المحكمون على إيجابية وسلبية عبارات المقياس، وأجمعوا أن التعليمات واضحة فى كراسة الطالبة، واقترح بعض السادة المحكمين نقل بعض العبارات من المحور الثاني إلي المحور الأول، وحذف عبارة من عباراتان مكررتان في المحور الأول، وق أجريت التعديلات المشار إليها. 
0- التجربة الاستطلاعية:

بعد عرض المقياس على السادة المحكمين أصبح المقياس فى صورته الأولية جاهزاً للتطبيق على العينة الاستطلاعية بهاف التعرف على مدى فهم الطالبات للتعليمات وطريقة الإجابة وكذلك الإجابة عن استفساراتهن، وكذلك حساب الصدق والثبات والمعاملات الإحصائية للمقياس، وحساب الزمن اللازم للاستجابة علي عبارات المقياس، وقد تم تطبيق المقياس بعد الاتتهاء من التجرية الاستطلاعية لموضوعات المقرر فى بداية الفصل الدراسي

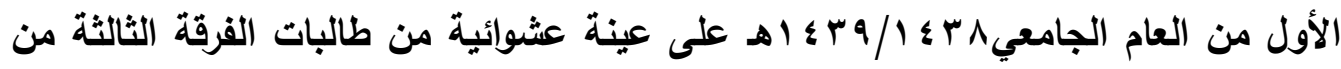

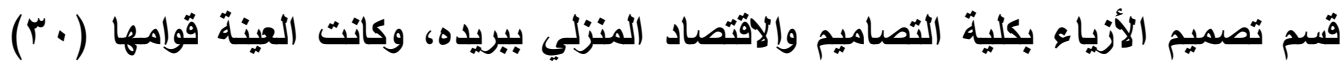
طالبة غير عينة البحث الأساسية وأسفرت التجربة الاستطلاعية عن وضوح التعليمات، لاءلية وكذلك عبارات المقياس، كما تم الرد عن استفسارات الطالبات بالقدر الأي يحقق لهن الإستجابة للمقياس بجدية، وقد تم تصحيح إجابات الطالبات، ورصد الدرجات،وتمت المعالجات الحسابية،وذلك بهدف: أ- صدق المقيـاس :يعتبر المقيـاس صـادقا عندما يقيس مـا وضـع لقياسـه، وقد اتبع البحث الحالي الطرق التالية فى معرفة صدق المقياس وهى: - الصلدق المنطقي :بهـف الحكم على مدى تمثيل المقياس للميدان الذى يقيسهـ وقد راعت الباحثة ذلك فى أثناء إعداد المقياس واتضح ذلك من خلال وجهة نظر السـادة المحكمين للمقياس. - صلدق المضمون:وتبين من خلال إجماع السادة المحكمين على أن كل عبارات المقياس تقيس الاتجاه نحو مقرر طرق تدريس خاصة( ) (1). - ساب الاتساق الداخلي:تم حساب معاملات الاتساق الداخلي للمقياس،كمؤثراً لصدقه، واتضح أن معاملات الارتباط دلاله عند مستوي دلالة(ه . . ·)، ويعني ذلك أن إرتباط محوري المقياس بالمقياس ككل، مما يؤكد أن المقياس يتمتع بدرجة عالية من الصدق. ب- ثبات المقياس:تم التحقق من ثبات المقياس من خـلال إعادة تطبيقه علي نفس العينة الاسـتطلاعية بفـارق شـهر واحـد بين التطبيقين بهـف استخراج معامـل ارتبـاط "بيرسـون"

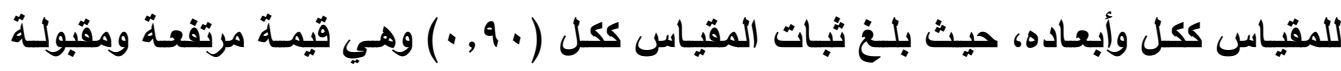


צ- زمن تطبيق المقياس: تم حسابه من خلال طريقة التسجيل التتابعي للزمن الذي استغرقته كل طالبة من طالبات العينة الاستطلاعية في الإجابة علي المقياس، وتم حساب متوسط هذه هن

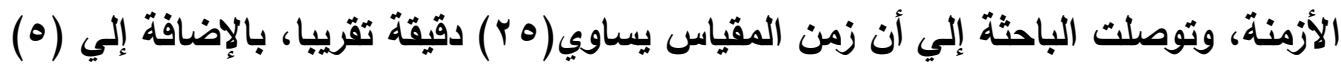
دقائق لقراءة التعليمات ، ويذلك أصبح المقياس جاهزاً للتطبيق على عينة البحث.

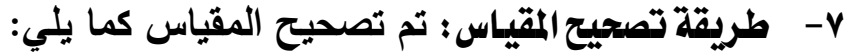

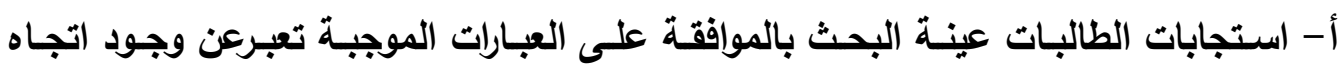
إيجابي للايهن نحو مقرر طرق تدريس خاصـة(1)، لذلك توزعت الدرجات على الاختيارات الثلاثة (موافقة - غير متأكدة - غير موافقة) كالتالي (r-r - - I ) على الترتيب. ب- استجابات الطالبات عينة البحث بالموافقة على العبارات السالبة تعبر عن وجود اتجاه سلبي للايهن نحو مقرر طرق تدريس خاصـة(1)، لذلك توزعت الدرجات على الاختيـارات

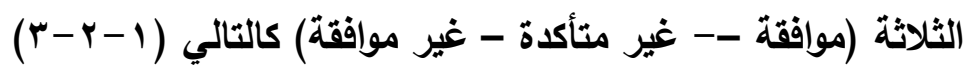
^- الصورة النهائية للمقياس : أصبح المقياس في صورته النهائية مكونا من محورين تضمنا (Y \& ) عبارة. ملحق (9) نتائج البحث وتقسيرهـا : قامت الباحثة برصد درجات الطالبات عينة البحث قبليا ويعدياً لأدوات البحث وتحليلها للتحقق من صحة فروض البحث والإجابة عن تساؤلاته وأجرت الباحثة المعالجات والأسـاليب

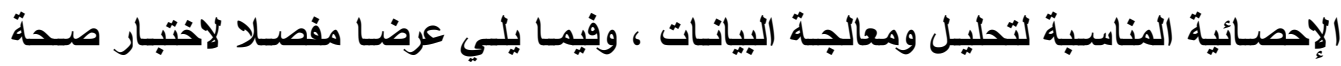

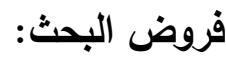

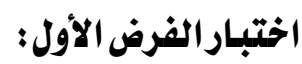

للتحقق من صحة الفرض الأول الذي نص على:" يوجد فرق ذو دلالة إحصائية عند مستوي دلالة (ه., •) بين متوسطي درجات تحصيل طالبات المجموعة التجريبية اللاتي درسن وفقا لاستراتيجية(K.W.L)، وطالبات المجموعة الضابطة اللاتي درسن بالطريقة التقليدية في التطبيق البعدي لاختبار التحصيل المعرفي لصالح طالبات المجموعة التجريبية. تم حساب اختبار "ت" لعينتين مستقلتين لمتوسطي درجات إجابات الطالبات مجموعتي البحث (الضابطة و التجريبية) في اختبار التحصيل المعرفي، وجدول (ب) يوضح ذلك. 
" فاعلية استخدام استراتيجية (K. W.L) في تدريس مقرر طرق التدريس .

جدال

نتائج قيمة "ت" لعينتين مستقلتين ودلالتها الإحصائية للفرق بين متوسطي درجات طالبات المجموعتين

\begin{tabular}{|c|c|c|c|c|c|c|c|}
\hline الالالة & مستوى الدلالة & المحسوبة & الدرجة & عددالعينـة & الالنحر افياري & الحستبي & المجموعة \\
\hline \multirow{2}{*}{ دالة } & \multirow{2}{*}{$(\cdot .0)$} & \multirow{2}{*}{$r o, \cdot v$} & \multirow{2}{*}{ Tr } & $r r$ & $r, r q$ & $r r, V I$ & الضابطة \\
\hline & & & & Tr & $r, r v$ & $\varepsilon \varepsilon, \Gamma q$ & التجريبية \\
\hline
\end{tabular}

اتضح من جدول (r) أن قيمة "ت" المحسوية للتحصيل المعرفي أكبر بكثير من قيمة

"ت" الجدولية وأن هناك فرقا دالا إحصائيا بين متوسطي درجات طالبات المجموعة التجريبية

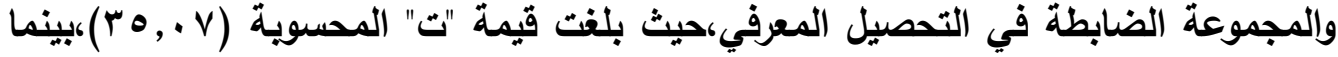
قيمة"ت" الجدولية لالالة الطرفين ودرجة حرية (r (7) تساوي (99, I) عند مستوي دلالة (0., •)، ويتضح من ذلك أن طالبات المجموعة التجريبية اللاتي درسن موضوعات مفرر طرق تدريس خاصة(1) قد تفوقن على طالبات المجموعة الضابطة اللاتي درسن نفس هرس الموضوعات بالطريقة التقليدية، وذلك في التطبيق البعدي لاختبار التحصيل المعرفي، ويعني هذا وجود فرقا دالا إحصائيا عند مستوى دلالة (ه...) بين متوسطي درجات طالبات المجموعة التجريبية و طالبات المجموعة الضابطة في التطبيق البعدي للاختبار لصالح طالبات المجموعة التجريبية، وعليه تم قبول الفرض الأول من فروض البحث الحالي،

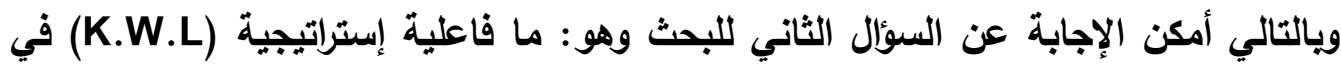
تنمية التحصيل المعرفي لاي الطالبات عينة البحث؟ الاجه عن البه وقد أرجعت الباحثة تحسن مستوي التحصيل المعرفي لاي طالبات المجموعة التجريبية إلي أن استراتيجية (K.W.L) ساعدت الطالبة علي أن:

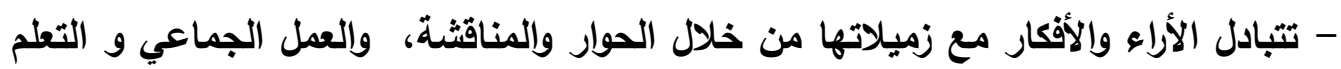
التعاوني. - تنشط معرفتها السابقة؛ لأنها هي التي تفكر وتحلل وتستنتج وتناقش موضوعات المقرر مع معلمتها وزميلاتها؛ فهي محور العملية التعليمية في هذه الإستراتيجية. - تقوم بتلخيص الموضوع بعد دراسته؛ مما يجعله أبقي أثرها في ذهنها. 
- تحدد أهدافها، وتنظم معارفها، وتراقب تعلمها، وتقيم أدائها؛ مما يسهم في تنظيم بُناها

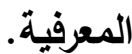
- تنخرط في العديد من الأنشطة التعليمية، مما أضفي علي العملية التعليمية تثويقا ومتعة لها. - تحدد الأفكار الرئيسة لكل موضوع من موضوعات المقرر، وريط معارفها السابقة بالمعلومات الجديدة المتعلمه، حيث تقوم الطالبة باستدعاء خبراتها السابقة حول منال الموضوع، وتضع الأسئلة المتضمنة بحقول الاستراتيجية، وهي:( ماذا أعرف عن الموضوع؟ - ماذا أريا معرفته عن الموضوع؟ - ما الأي تعلمته عن الموضوع؟). - تقرأ بالطريقة التي يستخدمها القراء الخبراء في معالجة النصوص ، ودمج ما يقرأون في معارفهم الخاصة، مما يدعم الفهم والاستيعاب لايها. في ضوء ما سبق فإن استراتيجية (k.w.I) فعالة في التعليم والتعلم واكساب الطالبات المعارف، و سهولة فهمها، وتحليلها والاحتفاظ بها ، ودمجها مع المعرفة السابقة المرتبطة بموضوعات المقرر؛ مما أدي إلي تحسن التحصيل المعرفي، فضلا عن أن المعلمة عندما تعرف وتحدد بوضوح الأهداف التعليمية، وتشرك معها الطالبات- كما حدث بهذه

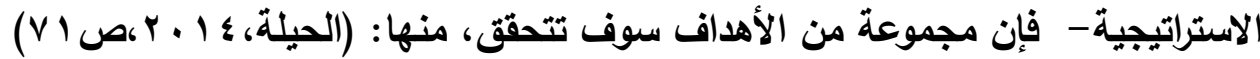
أ- الحصول علي تعلم أفضل. ب-تحقيق نتائج تعليمية أكثر فاعلية.

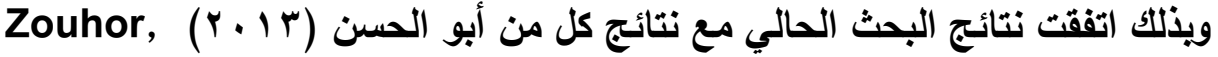
Bogdanovic and Segedinac (2016) باستخلام إستراتيجية (K.W.L). ولكن في مجالات أخري، بينما اختلفت مع نتائج دراسة

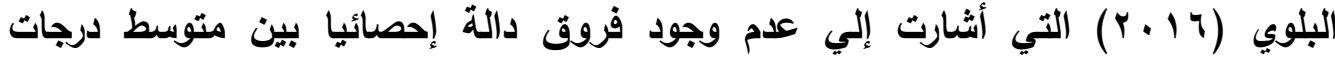
المجموعة التجريبية في التطبيق البعدي والمؤجل للاختبار التحصيلي. ولحساب حجم تأثير إستراتيجية (k.w.I) في تحسين التحصيل المعرفي تم استخدام

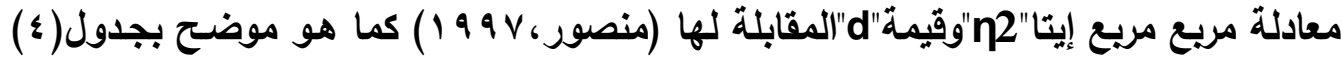

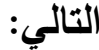


" فاعلية استخدام استراتيجية (K. W.L) في تدريس مقرر طرق التدريس .

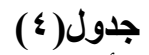

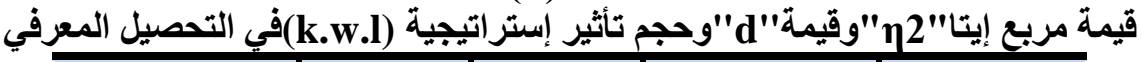

\begin{tabular}{|c|c|c|c|c|}
\hline دلالة حجثم & قيمة"d" & "قيمة2" & المتغير التابع & المستقلير \\
\hline ير جداً & $\varepsilon, r \varepsilon$ & .90 & المعرفي & $\begin{array}{c}\text { إستراتيجية } \\
\text { (k.w.l) }\end{array}$ \\
\hline
\end{tabular}

يتضــح مـن جـدول(ع ) أن حجـم تـأثير المتغيـر المسـتقل(k.W.I) علـي المتغيـر

التابع(التحصيل المعرفي) جاعكبير لصالح المجموعة التجريبية.

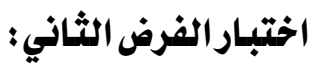

وللتحقق من صحة الفرض الثاني للبحث الحالي والذي نص على" يوجد فرق ذو

دلالة إحصائية عند مستوي دلالة (ه . . •) بين متوسطي درجات طالبات المجموعة التجريبية

اللاتــي درسـن وفقـا لاسـتراتيجية(K.W.L)، وطالبـات المجموعـة الضــابطة اللاتــي درسـن

بالطريقة التقليدية في التطبيق البعدي لمقياس الاتجاه نحو مقرر طرق تدريس خاصـة(1) لصالح طالبات المجموعة التجريبية".

تـم أيضـا حسـاب اختبار "ت" لعينتين مسـتقلتين لمتوسـطي درجـات اسـتجابات

الطالبـات مجموعتي البحث(التجريبيـة والضـابطة) في التطبيق البعدي لمقيـاس الاتجـاه نحو مقرر طرق تدريس خاصة(1)، وجدول (0) يوضح ذللك. جدول (0)

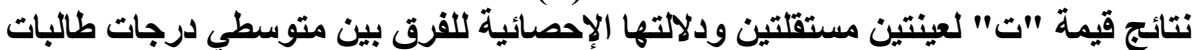
المجموعتين (التجريبية والضابطة) في التطبيق البعدي لمقياس الاتجاه نحو مقرر طرق تدريس دريس

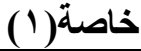

\begin{tabular}{|c|c|c|c|c|c|c|c|c|c|}
\hline \multirow{2}{*}{ الدلالة } & \multirow{2}{*}{ قامة المسو } & \multirow{2}{*}{ لرجة } & \multicolumn{3}{|c|}{ المجموعة الضابطة } & \multicolumn{3}{|c|}{ المجموعة التجريبية } & \multirow{2}{*}{ المجموعة المحاور } \\
\hline & & & الالمعياري اف & المتو & العد & الالنحر افي & المتوسط & العدد & \\
\hline $\begin{array}{c}\cdot 0) \\
(\end{array}$ & rY, ro & $7 r$ & 1,01 & $1 T, 8$ & $r r$ & $r, r V$ & $r \otimes, \Lambda$ & rr & المقرر \\
\hline$\left.\because 0^{0}\right)$ & $19, \wedge r$ & $7 r$ & 1,99 & IV, & rr & $1, v r$ & $r r, q 1$ & Mr & الاستمتاع المقرة \\
\hline$\because 0)$ & $r r, \wedge q$ & $7 r$ & $r, r r$ & 11,0 & rr & $r, 10$ & $r r, \varepsilon q$ & rr & ككل المقياس \\
\hline
\end{tabular}




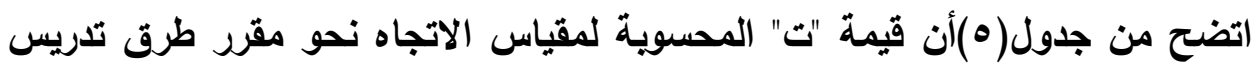

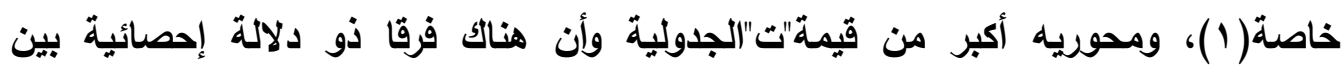

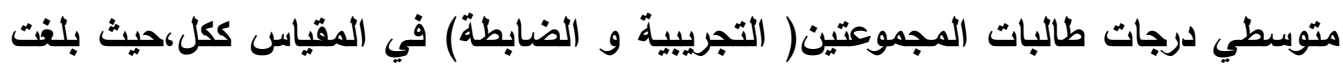

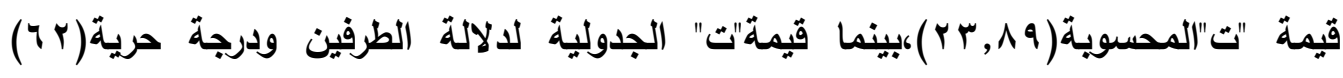

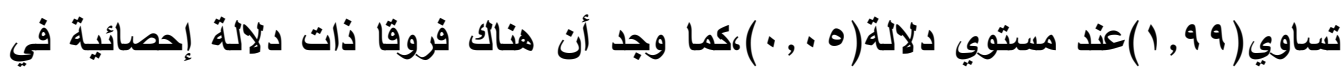

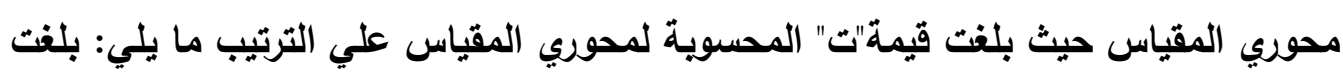

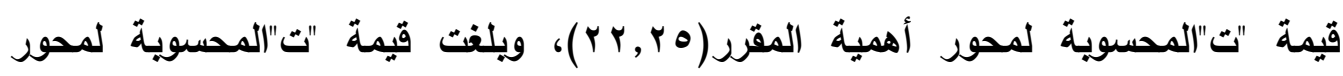

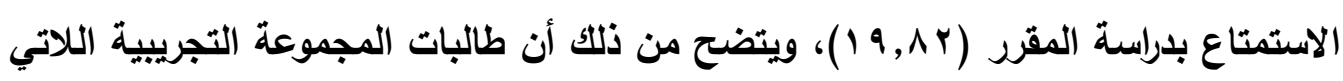

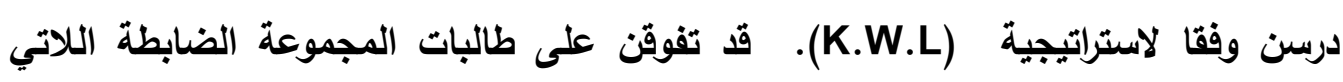

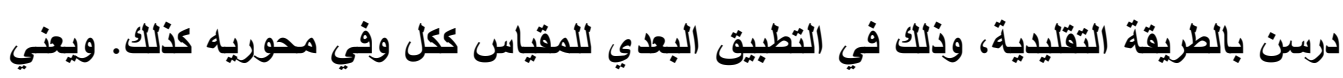

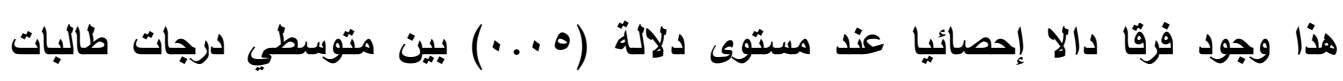
المجموعة التجريبية و طالبات المجموعة الضابطة في التطبيق البعدي للمقياس لصات لصالح

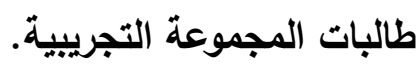
وعليه وعليه تم قبول الفرض الثاني من فروض البحث الحالي، ويالتالي أمكن الإجابة

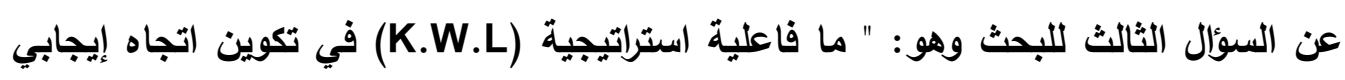

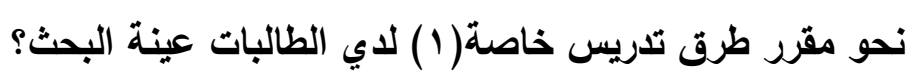

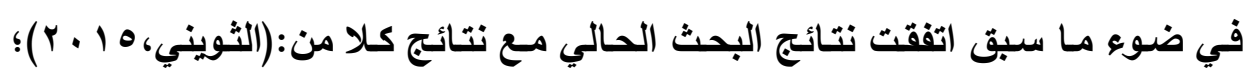

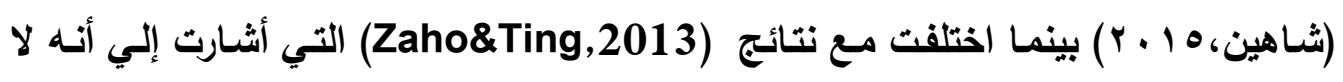
توجد علاقة إيجابية أو سلبية بين معرفة الطلاب لطرق التدريس واتجاهاتهم نحوها.

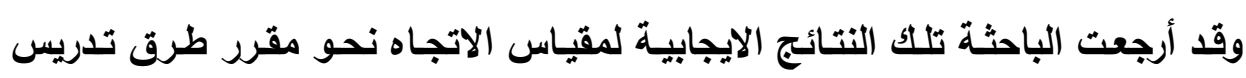

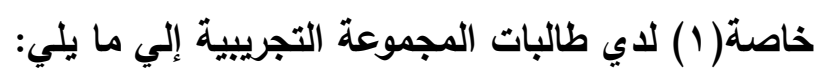

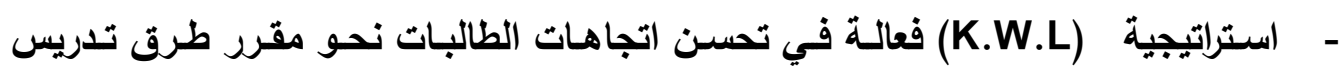

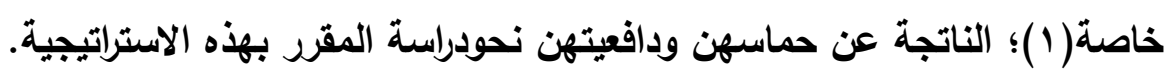

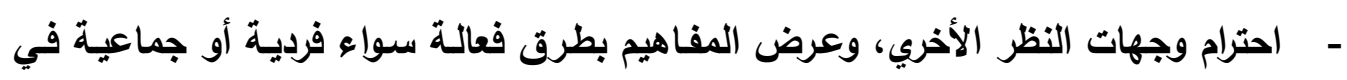

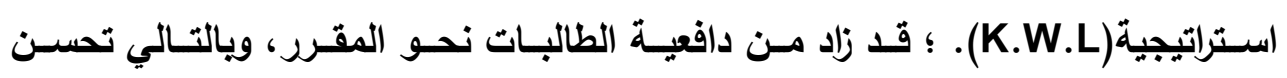

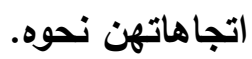


كانت مشوقة في عرض موضوعات المقرر؛ ممـا زاد من حب

- استراتيجية) -

الطالبات للمقرر، ورغبتهن في دراسته.

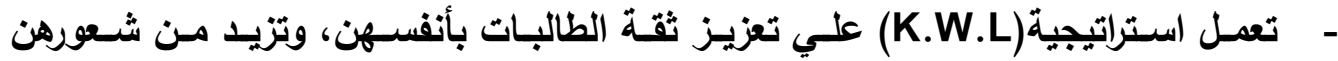
بمسؤولية تعلمهن؛ مما أدي إلي تحسن اتجاهاتهن نحو المقرر. - مراعاة حاجات الطالبات، والتمحور حولهن، وحفز دافعيتهن، وتشجع التعلم الذاتي ، وتتمية مهارات تحمل المسؤولية لايهن.

- الاتجاهات من نواتج التعلم الأكثر بقاءً لاي الطالبات خلاف المعارف التي سرعان ما

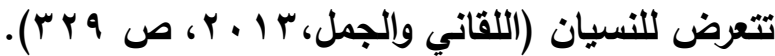
ولحسـاب حجم تأثير استراتيجية (K.W.L) في تكون اتجاهـات إيجابية نحو مقرر طرق

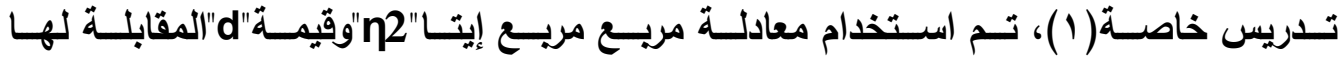

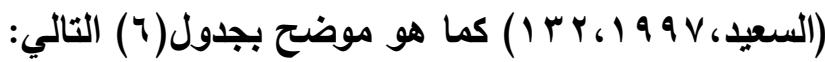

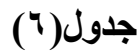

قيمة مربع إيتا"Y2"وقيمة"d"وحجم تأثير إستراتيجية (K.W.L). في مقياس الاتجاه نحو مقرر

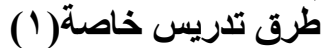

\begin{tabular}{|c|c|c|c|c|}
\hline 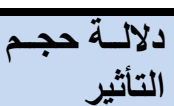 & "قيمة"d" & 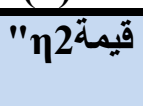 & المتغير التابع & المتغير المستقل \\
\hline كبير جداً & $0, \leqslant 1$ & $\cdot, \wedge \Lambda$ & أهمية بالمقرر & \multirow{3}{*}{$\begin{array}{l}\text { إستر اتيجية } \\
\text { (K.W.L) }\end{array}$} \\
\hline كبير جداً & $\varepsilon, 9$ & $\cdot, \wedge 4$ & الاستمتاع بلدراسة & \\
\hline كبير جداً & 7 &., 9 . & المقياس ككل & \\
\hline
\end{tabular}

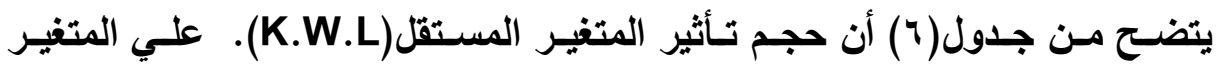
التابع(مقيـاس الاتجـاه نحو مقـر طرق تـريس خاصـة(1)، ومحوريـه) جـاء كبيـرا لصـالح المجموعة التجريبية.

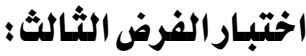
وللتحقق من صحة الفرض الثالث للبحث الحـالي والذي نص علي" توجد علاقة ذات دلالــة إحصـائية عنـــ مسـتوي دلالـة (ه . , •) بـين تحصسيل طالبـات المجموعـة التجريبيـة واتجاهـاتهن نحو مقرر طرق تدريس خاصـة (1)"، تم إيجاد معامل الإرتباط بين التحصيل المعرفي للطالبـات واتجاهـاتهن نحو مقرر طرق تـريس خاصـة (1) بعديا، وذلك باستخدام

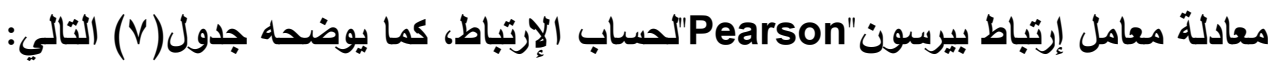




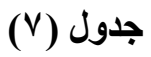

العلاقة الإرتباطية بين متوسط درجات اختبار التحصيل المعرفي ومقياس الاتجاه نحو مقرر طرق

\begin{tabular}{|c|c|c|}
\hline \multicolumn{3}{|c|}{ تدريس خاصة( ) في القياس ألبعدي } \\
\hline مستوي الدلالة & معامل الإرتباط بين & عدد المجموعة التجريبية \\
\hline$*, \cdots 1$ & $\cdot, \wedge 9$ & Mr \\
\hline
\end{tabular}

اتضح من الجدول(V) وجود علاقة إرتباطيه موجبة بلغت(9 9 ( • ) بين متوسط درجات الطالبات في اختبار التحصيل المعرفي ويين متوسط إجاباتهن علي مقياس الاتجاه نحو مقرر طرق تدريس خاصة(1)، وهي علاقة ذات دلالة إحصائية عند مستوي الدلالة (1 ( . . . •)،ويهذا تم قبول الفرض الثالث من البحث الحالي. وتعزي هذه النتيجة إلي أن : - استراتيجية(K.W.L) لا تقف عند حدود الكتاب المقرر للتزود بالمعرفة، ممـا يجعل الطالبة تنوع مصادر تعلمها. - تحسن مستوي الطالبات في تحصيل الجوانب المعرفية بالمقرر؛ أدي إلي تكون اتجاها إيجابيا نحوه.

- تعل استراتيجية (K.W.L) علي جذب انتباه الطالبات، وتحفيز اهتمامهن خلال دراسة موضوعات المقرر، الأمر الأي أدى الى متابعة الطالبات المستمرة وإنتاج أكبر عدد ممكن من الأسئلة التي يرغبن في تعلمها، مما أدي إلي سهولة التعلم، وتحسن في التحصيل. - اتجاه الطالبات الإيجابي نحو مقرر طرق التّريس ؛ ساعد علي إنجاز والتحصيل.

\section{التوصيات: - ات}

في ضوء ما توصل إليه البحث من نتائج يقديم التوصيات التالية: - ضضمين برنامج إعداد المعلمات بكليات الإعداد للاستراتيجيات والطرائق الحديثة في التدريس مثل إستراتيجية (K.W.L) للإستفادة منها في ممارسة المهنة بعد التخرج. - الاستعانة باستراتيجية(K.W.L) في تلريس المقررات التريوية بقسم تصميم الأزياء بشكل عام ويمقرر طرق تدريس خاصة( (1) بشكل خاص. 
- توجيه معلمات التربية الأسرية إلي عدم الاقتصار علي الطرق التقليدية في التدريس

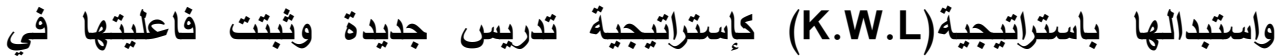
التدريس.

- - ت تدريب أعضاء هيئة التريس - تزويد المعلمات بالمزيد من المعلومات حول استراتيجيات التفكير فوق المعرفي كاستراتيجية(K.W.L) ، وأهميتها،وكيفية استخذامها.

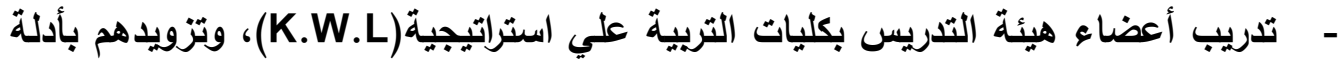
ترشدهم لاستخدامها في التدريس. - مساعدة الطالبات علي زيادة اتجاهاتن ودافعيتهن نحو مقررات طرق تدريس الاقتصاد

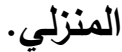
- مث الباحثين في مجال طرق التريس علي إجراء مزيد من الدارات والبحوث حول استراتيجية في مختلف التخصصات. فتح مجال كبيرلإجراء المزيد من البحوث والدراسات المتعلقة باستراتيجيات التفكير فوق فئقات المعرفي كاستراتيجية(K.W.L).

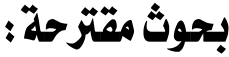

في ضوء نتائج البحث الحالي وتوصياته تقترح الباحثة إجراء البحوث والدراسات

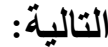
- فعالية استخدام استراتيجية (K.W.L) في تدريس مقرر التربية الأسرية والصحية لتنمية مهارات التفكيرالأبداعي و العلمي لاي طالبات المرحلة الثانوية.

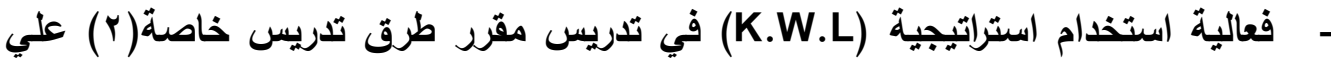
تنمية مهارات التفكيرلدي الطالبات معلمات التربية الأسرية. الفهم الخطأ لاي الطالبات معلمات التربية الأسرية.

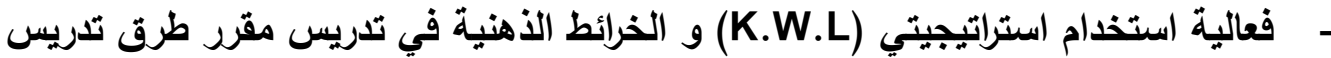
الاقتصاد المنزلي علي تنمية التحصيل، ومهارات التفاوض لاي الطالبات المعلمات. 


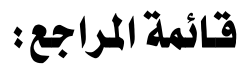

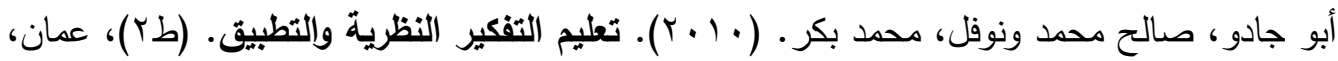
الأردن: دار الدسبرة للنشر والتوزيع.

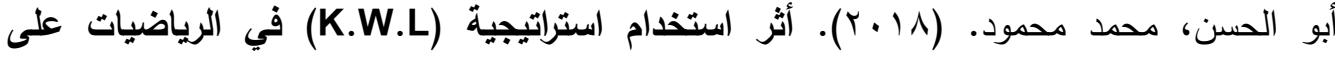
التحصيل الاراسي لطلاب الصف السادس الأساسي بالمنطقة الثرقية حكومة الثارقة، مجلس الثارقة الثرانة • للتعليم

Retrieved from: http://sharjahaward.shae/uploas/Award/Issue/ eb7a 37da417-4b76-82f0-9b6469263a95122-1-115335-724.pdf

أبو حطب، فؤاد وصادق، أمال. (r/.ب).علم النفس التريوي. (طج)، القاهرة: مكتبة الأنجلو المصرية.

البلوي، عايد علي محمد. (T ب). أثز التدريس باستخدام استراتيجية (K.W.L) على تحصيل طلاب

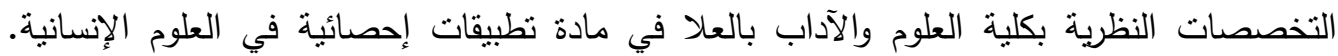
المجلة الدولية التريوية المتخصصة، (ع)، . ـ ب-255.

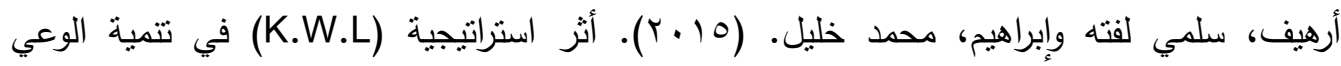

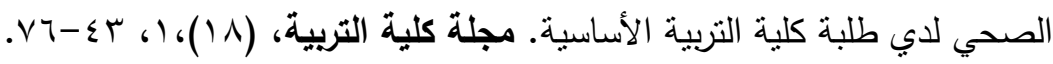

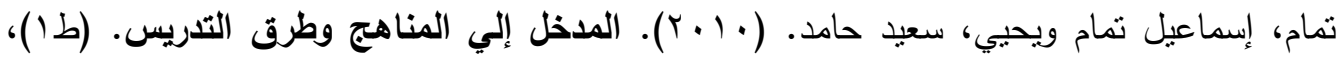

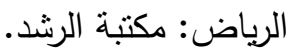
الثويني، سليمان ناصر • (10 ب). فاعلية التنريس المصغر في تنمية المهارات التدريسية لطلاب

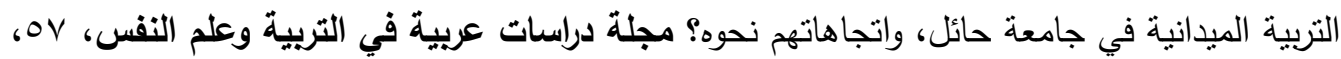
.r..-IVT

جامعة القصيم.(10 + Y). دليل الطالب للمناهج بكلية التصاميم والاقتصاد المنزلي. بريده.

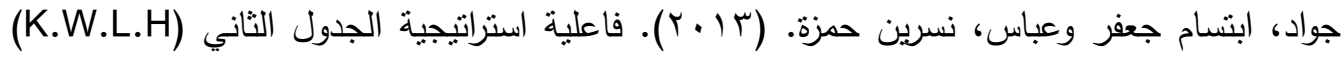
في تنمية مهارات التفكير العلمي لاى طالبات الصف الثاني الدنوسط في مادة الفيزياء Retrieved from www.uobabylon.edu.iq/publication/ basic_edition13/basic_ed13_32.doc.

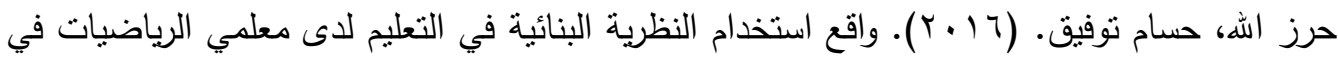

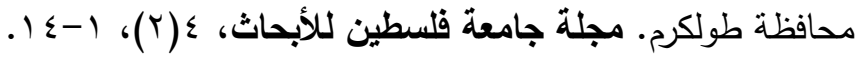




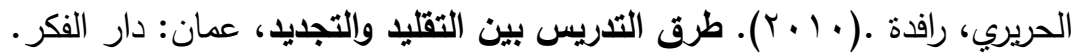

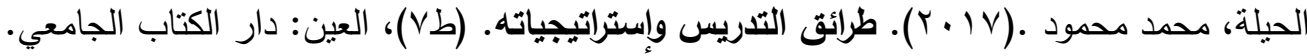
الحيلة، محمد محمود. (ع ( ب). مهارات التدريس الصفي. (ط )ء، عمان: دار المسيرة للنشر والتوزيع

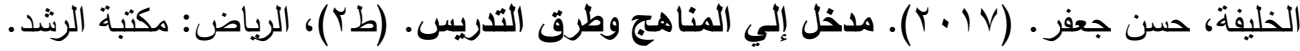
الداهري،صالح حسن. (11 •r). أساسيات علم النفس التربوي ونظريات التعلم. عمان: دار الحامد للنشر والتوزبع.

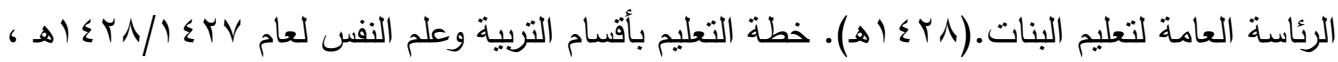
دليل أقسام التربية وعلم النفس، وزارة التربية والتعليم، المملكة العربية السعودية.

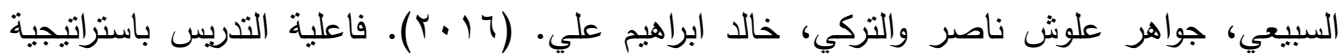
في تصويب انماط الفهم الخطأ في بعض مفاهيم مقرر الحاسب الآلي لدى طالبات الصف (K.W.L)

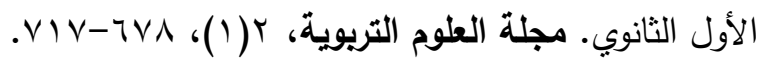
الثافعي،محمد منصور • (ع ( ب). الإحصاء التقليدي والمتقدم في البحوث التربوية. الرياض: مكتبة الرشّد. شاهين،عبد الرحمن يوسف .(10 • ( ). اتجاهات طلاب الجامعة الإسلامية نحو مقرر طرق التدريس

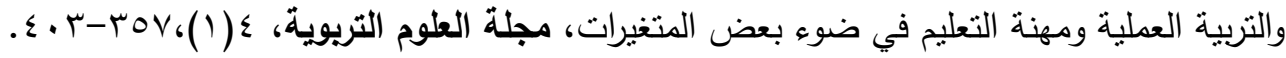
صالح، حسن أحمد. (1 ( • (1). أساسيات علم التفس التريوي ونظريات التعلم. عمان:دار الحامد للنشر والتوزيع.

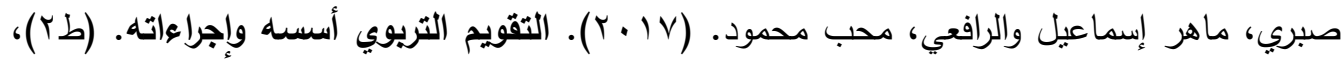
الرياض: مكتبة ارشد. طياب، محمد. (r ( • (r). الاتجاه نحو مهنة التدريس وعلاقته بالأداء التدريسي لدي أساتذة التربية

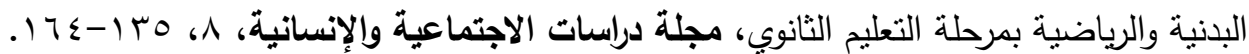
عبد الباري، ماهر شعبان. ( • ( (Y). استراتيجيات فهم المقروء. عمان، الأردن: دار المسيرة.

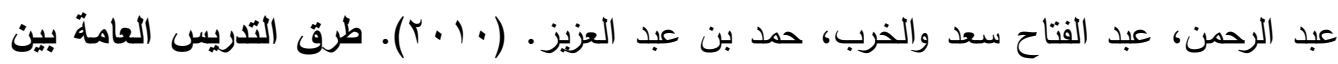
التقليد والتجديد. (ط ا)، الرياض: مكتبة الرثد. عبد الكريم، منذر مبدر وعاشور، محمد ابراهيم وعبيد، كامل كريم. (11 (Y). فاعلية تطبيق

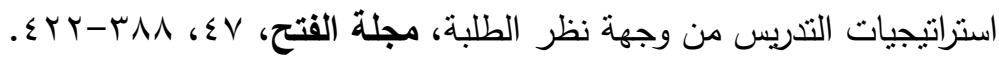

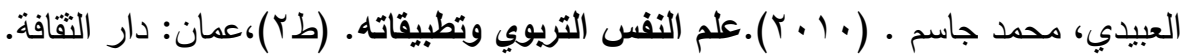


العتيبي، فاطمة قاسي دهيس. (10 (Y.W.L) فاعلية استراتيجية (K.W) في تدريس السيرة النبوية على تنمية القيم الخلفية والوعي بها لاى تلميذات المرحلة الابتدائية، رسالة ماجستير غير منشورة، قسم

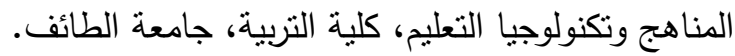
عرام، ميرفت سليمان عبد الله. (Y (Y. Y). أثر استخدام استراتيجية (K.W.L) في اكتساب المفاهيم ومهارات التفكير الناقد في العلوم لاى طالبات الصف السابع الأساسي، رسالة ماجستير غير منشورة،

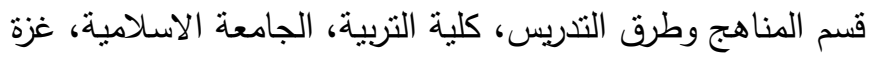
Retrieved from : library.iugaza.edu.ps/thesis/102744.pdf عطية، محسن علي. (· • (Y). استراتيجيات ما وراء المعرفة في فهم المقروء. عمان: دار المناهج للنشر والتوزيع. عمران، خالد عبد اللطيف. (• ( • (ب). فاعلية مقرر الكتروني مقترح في تدريس الدراسات الاجتماعية على التحصيل وتتمية مهارات التواصل الإككتروني والاتجاه نحو مهنة التدريس لدى طلاب كلية التربية،

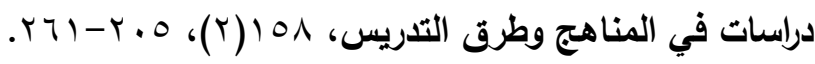

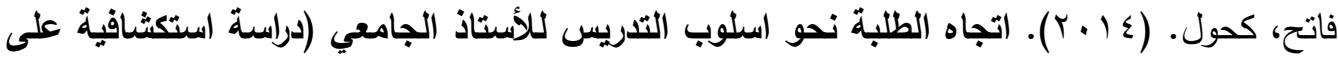
عينة من طلبة جامعة ورقلة)، رسالة ماجستير غير منشورة، قسم علم النفس والعلوم التزبوية، كلية العلوم الإنسانية والاجتماعية، جامعة قاصدي مرباح ورقلة بالجزائر .

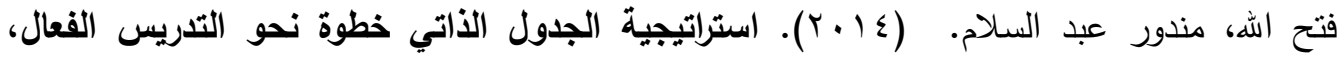
Retrieved from: http://www.almarefh.net الكسباني،محد السيد علي.(· ( •). مصطلحات في المناهج وطرق التدريس. الأسكندرية:دار حورس

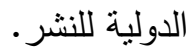

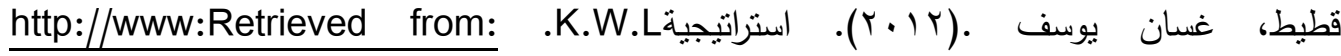
.ghassan-ktait.com

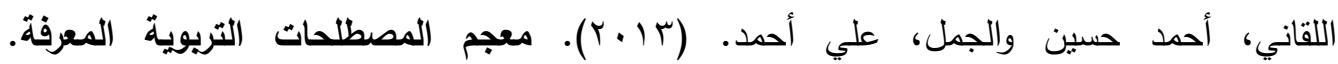

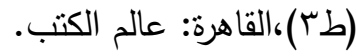
منصور، رشدي فام.(99V1). حجم تأثثر الوجه المكمل للالالة الإحصائية. القاهرة: مكتبة الأنجلو المسرسة.

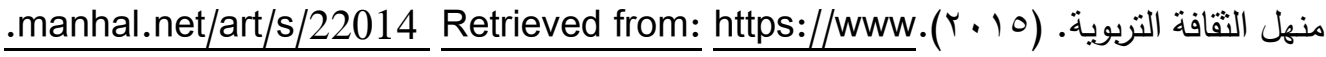
Retrieved from http://www.arab-ency.com الموسوعة العربية .(10 • ب). الاتجاهات، 


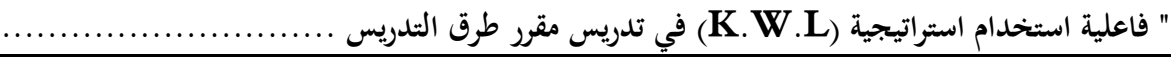

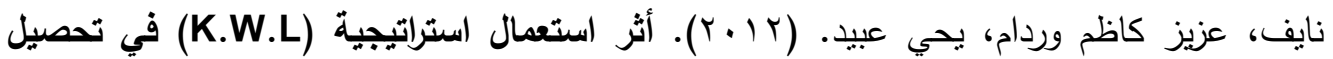
طلاب الصف الثاني المتوسط في مادة التاريخ العربي الإسلامي، رسالة ماجستير غير منشورة، قسم العلوم التزبوية والنفسية، كلية التزبية للعلوم الإنسانية، جامعة كربلاء.

Retrieved from: https://www.iasj.net/iasj?func=fulltext\&ald=7794

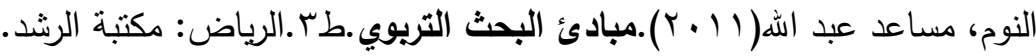

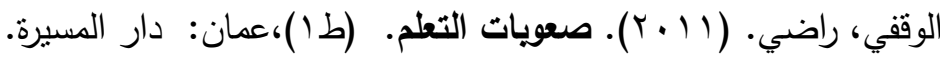

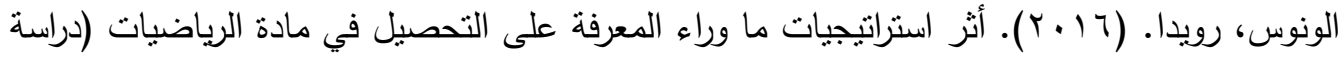

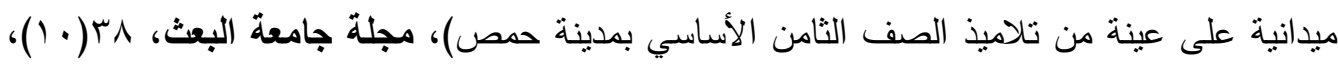
$.10 r-1 \leqslant r$

Edel-Malizia , S. (2015). Pedagogical Practices K-W-L Retrieved from: http://practicaledtech.com/2014/06/02/practical-ed-tech-tip-of-theweek-padletas-kwl-chart-and-more/.

Lauzon, N. (2014). KWL Strategy, Retrieved From: https://www. ldatschool.ca/the-kwl-strategy.

Logsdon, A. (2017). KWL Strategy Improves Reading Skills. This visual organizer can help students comprehend information, Retrieved From: https://www.verywellfamily.com/kwl-what-is-kwl-2162741

Kopp,K.(2010).Everyday Content-Area Writing: Write-Learn Strategies for Grades 3-5.second edition,Gainesville :Maupin House.

Tok,S.(2013).Effects of The Know-Want-Learn Strategy on Students, Mathematics Achievement ,Anxiety and Metacognitive Skills, Metacognition Learning, 8,193-212.

Risnawati, R and Lismayanti, D. (2014). The effect of using (KWL) Strategy of FEL Students, Reading Comprehension Achievement, International Journal of Humanities and Social Science, 4 (7), 225-223. Retrieved From: http:www.ijhssmet.com/journals/vol4 no71May 2014/28.pdf.

William, G. and Fredricka L. (2013). Teaching and Researching Reading London :Rutledge .

William Grabe and Fredricka L. Stoller.(2013).Teaching and Researching Reading .London :Rotledge.

Wulandari_S._(2017). The effect of using know-want to know-learned (KWL) strategy. Compression to the eighth-grade students of MTs $\mathrm{Ma}^{\mathrm{ee}}$ arif Balong in academic year 2016/2017. Master Thesis presented to the state institute of Islamic studies of Ponor ago Education and teachers training Faculty, Ponor go Indonesia. Retrieved From: https://scholar.najah.edu/sites/ default/files/ Areen\%20Abu \%20 Amsheh. pdf 
" فاعلية استخدام استراتيجية (K.W.L) في تدريس مقرر طرق الثدريس (K) و

Zaho, K and Ting, K. (2013). Student Attitudes Towards Teaching Methods Used in Universities the UK, Canadian Center of Science and Education, 5 (4), 71-81.

Zouhor, Z., Bogdanovic, I., and Segedinac M. (2016). Effects of the KnowWant-Learn Strategy on Primary School Students' Metacognition and Physics Achievement. Journal of Subject Didactics, 1(1), 39-49.

Zouhor, Z., Jaskov, M., and Bogdanovic, I. (2016). The Examples of Physics concepts Formation by The Use of KWL Strategy. The Eurasia Proceedings of Educational \& Social Sciences (EPESS), 4, 162-164. 